\title{
Replacement Therapy for Hypothyroidism with Thyroxine Alone Does Not Ensure Euthyroidism in All Tissues, as Studied in Thyroidectomized Rats
}

Héctor F. Escobar-Morreale, M. Jesús Obregón, Francisco Escobar del Rey, and Gabriella Morreale de Escobar Instituto de Investigaciones Biomédicas, Consejo Superior de Investigaciones Científicas y Universidad Autónoma, 28029 Madrid, Spain

\begin{abstract}
We have studied whether, or not, tissue-specific regulatory mechanisms provide normal 3,5,3'-triiodothyronine (T3) concentrations simultaneously in all tissues of a hypothyroid animal receiving thyroxine ( $\mathrm{T4}$ ), an assumption implicit in the replacement therapy of hypothyroid patients with $\mathrm{T} 4$ alone.

Thyroidectomized rats were infused with placebo or 1 of $10 \mathrm{~T} 4$ doses $(0.2-8.0 \mu \mathrm{g}$ per 100 grams of body weight per day). Placebo-infused intact rats served as controls. Plasma and 10 tissues were obtained after 12-13 d of infusion. Plasma thyrotropin and plasma and tissue T4 and T3 were determined by RIA. Iodothyronine-deiodinase activities were assayed using cerebral cortex, liver, and lung.

No single dose of $\mathrm{T} 4$ was able to restore normal plasma thyrotropin, T4 and T3, as well as T4 and T3 in all tissues, or at least to restore $\mathrm{T} 3$ simultaneously in plasma and all tissues. Moreover, in most tissues, the dose of $\mathrm{T} 4$ needed to ensure normal T3 levels resulted in supraphysiological T4 concentrations. Notable exceptions were the cortex, brown adipose tissue, and cerebellum, which maintained T3 homeostasis over a wide range of plasma $\mathrm{T} 4$ and $\mathrm{T} 3$ levels. Deiodinase activities explained some, but not all, of the tis-
\end{abstract}

This work was presented in part at the 21st and 22nd Meetings of the European Thyroid Association, Cardiff, United Kingdom, July 1993, and Vienna, September 1994, the 67th Annual Meeting of the American Thyroid Association, Tampa, FL, November 1993, and the 76th Meeting of the Endocrine Society, Anaheim, CA, June 1994.

Address correspondence to Héctor F. Escobar-Morreale, Instituto de Investigaciones Biomédicas, Consejo Superior de Investigaciones Científicas y Universidad Autónoma, Arturo Duperier 4, 28029 Madrid, Spain. Phone: 34-1-397-54-00; FAX: 34-1-585-45-87; E-mail: gmorreale@mvax.fmed.uam.es. Héctor F. Escobar-Morreale's present address is Servicio de Endocrinología, Hospital Ramón y Cajal, Carretera de Colmenar Km. 9.1, 28034 Madrid, Spain.

Received for publication 28 June 1995 and accepted in revised form 7 September 1995.

1. Abbreviations used in this paper: 5'D-I, type I $5^{\prime}$-iodothyronine deiodinase; 5' D-II, type II 5 '-iodothyronine deiodinase; 5D-III, 5-deiodinase; BAT, brown adipose tissue (interscapular pads); BW, body weight; $\mathrm{Cb}$, cerebellum; $\mathrm{Cx}$, cerebral cortex; d.f., degrees of freedom; $\mathrm{H}$, heart; K, kidney; L, liver; Lu, lung; Mu, skeletal muscle (musculus quadriceps femoris); Pl, plasma; PTU, 2- $N$-propyl-6-thiouracil; $\mathbf{R}^{2}$, coefficient of determination; rT3, reverse $3,5^{\prime}, 3^{\prime}$-triiodothyronine; $S$, spleen; T3, 3,5,3' 'triiodothyronine; T3S, 3,5,3'-triiodothyronine sulfate; T4, thyroxine; TSH, thyroid-stimulating hormone.

J. Clin. Invest.

(c) The American Society for Clinical Investigation, Inc.

$0021-9738 / 95 / 12 / 2828 / 11 \quad \$ 2.00$

Volume 96, December 1995, 2828-2838 sue-specific and dose-related changes in tissue $\mathbf{T} 3$ concentrations.

In conclusion, euthyroidism is not restored in plasma and all tissues of thyroidectomized rats on $\mathrm{T} 4$ alone. These results may well be pertinent to patients on $T 4$ replacement therapy. (J. Clin. Invest. 1995. 96:2828-2838.) Key words: thyroid hormones - triiodothyronine - thyrotropin - iodothyronine-deiodinases $\bullet$ hypothyroid

\section{Introduction}

The thyroid gland secretes thyroxine (T4) ${ }^{1}$ and $3,5,3^{\prime}$-triiodothyronine (T3), with $\mathrm{T} 4$ as the quantitative major secretory product in most species studied so far. The molar ratio of the two iodothyronines, as secreted by the gland, has been calculated as 14:1 in adult humans (1), with the corresponding mean value obtained for the adult male rat being $\sim 6: 1(2-5)$. Although thyroidal synthesis and secretion are the only major source of T4 for extrathyroidal tissues, $\mathrm{T} 3$ secreted by the gland represents a relatively minor source of T3. Intracellular T3 is derived from two sources: circulating T3, and local conversion of T4 to T3. The former is, moreover, not entirely derived from the thyroidal secretion of $\mathrm{T} 3$, as a large proportion of circulating $\mathrm{T} 3$ has been generated from $\mathrm{T} 4$ in different tissues, and then released into the circulation. It was initially believed that circulating $\mathrm{T} 3$ would be in rapid and complete exchange with all of the T3 in extrathyroidal tissues, whether derived from the circulation or generated locally from T4. Therefore, under steady state conditions normal circulating T3 levels ought to ensure normal levels of T3 in all tissues. Studies from our laboratory $(6,7)$, however, questioned this assumption. Triiodothyronine generated locally from T4 is not necessarily in rapid or complete equilibrium with circulating $\mathrm{T} 3$ in all tissues, and therefore cannot be readily quantified from serum T3 levels and the tissue to plasma T3 ratio for that tissue, as determined with labeled T3. This was shown independently for anterior pituitary nuclear T3 by Silva and Larsen (8), and the important role of tissue deiodinative pathways for the regulation of intracellular sources of T3 was established (9). Different iodothyronine deiodinases were characterized and their different responses to thyroid status established $(10,11)$.

The relative contribution of T3 derived as such from the circulation and $\mathrm{T} 3$ generated locally from $\mathrm{T} 4$ has been measured for many tissues in the rat: it is not the same for all tissues and may, moreover, change in opposite manner in the same or different tissues during the life cycle, or when the animal is faced with alterations in thyroid hormone status, metabolic imbalances, treatments with drugs, etc. $(2-5,12-24)$. The observed changes in the relative contribution of both tissue sources of T3 are often in conceptual agreement with changes in the activities of the different iodothyronine deiodinases, as detected in vitro, although this is not always the case. Our knowledge regarding the roles of nondeiodinative pathways of $\mathrm{T} 4$ and $\mathrm{T} 3$ metabolism in different tissues, or of factors regulating the uptake and exit of iodothyronines is very fragmentary $(25,26)$. 
Despite the many gaps in our knowledge, it would appear likely that those tissues which derive most of their T3 from the circulation would have normal concentrations of $\mathrm{T} 3$ when circulating T3 levels are normal, whereas those tissues deriving all or most of their $\mathrm{T} 3$ by local generation from $\mathrm{T} 4$ would have normal $\mathrm{T} 3$ concentrations when plasma $\mathrm{T} 4$ is normal or somewhat elevated, provided the physiological responses to changes in thyroid status of the different deiodinases and of other regulatory mechanisms are not impaired. Normalization of circulating thyroid-stimulating hormone (TSH) is usually taken as confirmation that this has occurred. An athyrotic rat receiving $\mathrm{T} 4$ alone in amounts sufficient to ensure normal circulating levels of both iodothyronines ought to be able to compensate for the absence of thyroidal secretion of $\mathrm{T} 3$, a relatively minor source of T3 available to tissues. This assumption, however, has never been confirmed directly, although it is implicit in substitution therapies using $\mathrm{T} 4$ alone.

The oral administration of L-thyroxine $(27,28)$ is at present the widely accepted and recommended form of replacement therapy of hypothyroidism in humans. It therefore appeared of interest to clarify directly whether, or not, using $\mathrm{T} 4$ alone a euthyroid status is ensured simultaneously for all tissues. The experimental approach we have used is the direct determination of the concentrations of T4 and T3 in several tissues obtained from thyroidectomized rats on a constant subcutaneous infusion of T4. As will be seen, none of the 10 doses of T4 which we tested was adequate to ensure simultaneously a normal thyroid status of all the tissues studied.

\section{Methods}

Experimental design. Young female Wistar rats, weighing 120-150 grams, were surgically thyroidectomized. After $7 \mathrm{~d}$ a single $100-\mu \mathrm{C}$ dose of ${ }^{131} \mathrm{I}$ was injected intraperitoneally to eliminate thyroid remnants. $4 \mathrm{wk}$ later, rats with body weight (BW) stasis were subdivided in groups of six rats each, and osmotic minipumps (ALZET ${ }^{\circledR}$, model 2ML2; Alza Corp., Palo Alto, CA) were implanted under the dorsal skin of the animals.

Two separate experiments were performed. In experiment A the rats were infused either with placebo solution or with $\mathrm{T} 4$ at doses of 1.0, 2.0, 3.0, 4.0, and $8.0 \mu \mathrm{g}$ per 100 gram BW per day. In experiment B performed half a year later, the thyroidectomized rats were infused either with placebo or with $\mathrm{T} 4$ at doses of $0.2,0.4,0.6,0.8$, and $1.6 \mu \mathrm{g}$ per 100 gram BW per day. In both experiments, a control group of six intact rats was infused with placebo solution.

After 13 (experiment A) or 12 (experiment B) d of infusion the rats were slightly anesthetized with ether, bled extensively from the abdominal aorta after injection of a small amount (30-50 $\mu$ l) of heparin $(0.17 \%$ in $0.9 \% \mathrm{NaCl})$, and perfused with $50 \mathrm{ml}$ of PBS $(0.05 \mathrm{M}$ phosphate buffer containing $0.9 \% \mathrm{NaCl}, \mathrm{pH}=7.4)$. Samples of plasma (Pl), brown adipose tissue interscapular pads (BAT), pituitary, cerebral cortex $(\mathrm{Cx})$, cerebellum $(\mathrm{Cb})$, liver $(\mathrm{L})$, kidney $(\mathrm{K})$, heart $(\mathrm{H})$, lung $(\mathrm{Lu})$, spleen $(\mathrm{S})$, and muscle (musculus quadriceps femoris, $[\mathrm{Mu}]$ ), were obtained. Samples were rapidly frozen on dry ice and stored at $-20^{\circ} \mathrm{C}$ until analyzed for the present, or other, studies.

Determinations. Thyroxine and $\mathrm{T} 3$ were measured in whole plasm by specific and highly sensitive RIA as previously described (29), and in tissues after extraction and purification of the iodothyronines, as detailed elsewhere $(30,31)$. In brief, methanol is added to the still frozen tissue sample and homogenized. This avoids postmortem generation of $\mathrm{T} 3$ from T4, and degradation of T4 or T3 (31). Tracer amounts of $\left[{ }^{131} \mathrm{I}\right] \mathrm{T} 4$ and $\left[{ }^{125} \mathrm{I}\right] \mathrm{T} 3$ are added to each homogenate. This is followed by extraction of $>90 \%$ of the endogenous and added iodothyronines using chloroform/methanol (2:1). The iodothyronines are then backextracted into an aqueous phase, and purified by passing this aqueous phase through resin columns (AG $1 \times 2$; Bio-Rad Laboratories, Rich- mond, $\mathrm{CA}$ ). After a $\mathrm{pH}$ gradient, the iodothyronines are eluted with $70 \%$ acetic acid, which is then evaporated to dryness. Radioimmunoassay buffer is added and each extract is extensively counted to determine the recovery of the $\left[{ }^{131} \mathrm{I}\right] \mathrm{T} 4$ and $\left[{ }^{125} \mathrm{I}\right] \mathrm{T} 3$ added to each sample during the initial homogenization process; recovery usually varies between 50 $60 \%$ for $\left[{ }^{131} I\right] \mathrm{T} 4$ and $60-70 \%$ for $\left[{ }^{125} \mathrm{I}\right] \mathrm{T} 3$. The samples are submitted to highly sensitive RIAs for the determination of T4 and T3, the limits of sensitivity being $2.5 \mathrm{pg} \mathrm{T} 4$ and $1.5 \mathrm{pg} \mathrm{T} 3 /$ tube. Cross-reactivities of different iodothyronines and metabolites in the T4 and T3 RIAs were as recently reported (31). Each sample is processed in duplicate or triplicate at two or more dilutions. Concentrations are then calculated using the amounts of $\mathrm{T} 4$ and $\mathrm{T} 3$ found in the respective RIAs, the individual recovery of the $\left[{ }^{131} \mathrm{I}\right] \mathrm{T} 4$ and $\left[{ }^{125} \mathrm{I}\right] \mathrm{T} 3$ added to each sample during the initial homogenization process, and the weight of the tissue sample submitted to extraction. The amounts of tracers added are such that the radioactivities carried over into the RIA tubes are too low to interfere with the determinations, representing $<2.5 \%$ of the radioactivity added as labeled antigen.

Both T4 and T3 concentrations of a given tissue were determined in the same extraction run and a single RIA for each hormone. This limited the number of animals in one experiment to $<45$.

TSH was measured in plasma using immunoreactants kindly provided by the Rat Pituitary Agency of the National Institute of Diabetes, Digestive and Kidney Diseases (NIDKK, NIH, Bethesda, MD) as described elsewhere (32). Results are expressed in weight equivalents of the NIDDK r-TSH RP-3 preparation.

Type I 5 '-iodothyronine deiodinase ( 5 'D-I activity was assayed in $\mathrm{L}$ and $\mathrm{Lu}$ homogenates as described (33), using $400 \mathrm{nM}$ reverse $\mathrm{T} 3$ (rT3) and $2 \mathrm{mM}$ DTT for L, and $2 \mathrm{nM}$ rT3, and $20 \mathrm{mM}$ DTT for Lu in $100 \mathrm{mM}$ potassium phosphate buffer $(\mathrm{pH}=7.0), 1 \mathrm{mM}$ EDTA. The reaction time was $10 \mathrm{~min}$. for $\mathrm{L}$, and $60 \mathrm{~min}$ for Lu. Type II 5 'D ( 5 ' DII) activity was assayed in the $\mathrm{Cx}$ (34) using $2 \mathrm{nM}$ T4 $+1 \mu \mathrm{M} \mathrm{T} 3$ and $20 \mathrm{mM}$ DTT in the presence of $1 \mathrm{mM} 2-N$-propyl-6-thiouracil (PTU), and the reaction time was $60 \mathrm{~min}$. Before each assay [ $\left.{ }^{125} \mathrm{I}\right] \mathrm{rT} 3$ or [ $\left.{ }^{125} \mathrm{I}\right] \mathrm{T} 4$ was purified by paper electrophoresis to separate the contaminating iodide. The ${ }^{125} \mathrm{I}$-released was separated by ion-exchange chromatography on Dowex-50W-X2 (Bio-Rad Laboratories) columns equilibrated in $10 \%$ acetic acid. The production of equal amounts of iodide and 3',3-diiodothyronine was checked in some assays. The protein content was determined by the method of Lowry et al. (35), after precipitation of the homogenates with 10\% TCA to avoid interferences from DTT in the colorimetric reaction. Protein was usually $200 \mu \mathrm{g} / 100 \mu \mathrm{l}$ for most tissues, except for 10 times less when $\mathrm{L}$ was used.

5-deiodinase activity was measured in $\mathrm{Cx}$ homogenates (36), incubating $20-50 \mu \mathrm{g}$ protein $/ 100 \mu \mathrm{l}$ in $100 \mathrm{mM}$ potassium phosphate buffer $(\mathrm{pH}=7.4), 1 \mathrm{mM}$ EDTA with $\sim 50,000 \mathrm{cpm}$ of innerring-labeled [ $\left.{ }^{125} \mathrm{I}\right] \mathrm{T} 3$ (3,5-[ $\left.\left.{ }^{125} \mathrm{I}\right] \mathrm{T} 3\right), 50 \mathrm{nM} \mathrm{T3}, 20 \mathrm{mM}$ DTT, and $1 \mathrm{mM}$ PTU for $60 \mathrm{~min}$. at $37^{\circ} \mathrm{C}$. Radioiodide release was measured as above. When necessary, 3,5-[ $\left.{ }^{125} \mathrm{I}\right] \mathrm{T} 3$ was purified just before the assay using disposable Sep-Pak $\mathrm{C}_{18}$ cartridges (Waters Associates, Mildford, MA).

Drugs and reagents. Thyroxine, T3, 3,5-diiodothyronine, PTU, and DTT were obtained from Sigma Chemical Co. (St. Louis, MO). Reverse T3 and 3',3-diiodothyronine were obtained from Henning Berlin Gmbh (Berlin, Germany).

High specific activity $\left[{ }^{131} \mathrm{I}\right] \mathrm{T} 4,\left[{ }^{125} \mathrm{I}\right] \mathrm{T} 3,\left[{ }^{125} \mathrm{I}\right] \mathrm{T} 4$, and $\left[{ }^{125} \mathrm{I}\right] \mathrm{rT} 3$ $(3,000 \mu \mathrm{Ci} / \mu \mathrm{g})$ were synthesized in our laboratory, as previously described (30), and used for highly sensitive T4 and T3 RIAs, as recovery tracers for plasma and tissues extractions, and as substrates for $5^{\prime}$ deiodinases. The innerring-labeled $3,5-\left[{ }^{125} \mathrm{I}\right] \mathrm{T} 3(80 \mu \mathrm{Ci} / \mu \mathrm{g})$, used as substrate for 5-deiodinase (5D-III), was kindly provided by Drs. R. Thoma and H. Rökos from Henning Berlin Gmbh.

Statistical analysis. One-way ANOVA and protected least significant difference test for multiple comparisons were used, after validation of the homogeneity of variances by the Bartlett-Box $F$ test (37). Square root or logarithmic transformations usually ensured homogeneity of variances when this was not found with the raw data. Results are expressed as means \pm SEM. $P<0.05$ was considered significant in all comparisons. To assess the relationships between tissue and plasma T3 and T4 concentrations, individual paired data were adjusted to several 
Table I. Circulating Concentrations of T4, T3, and TSH, and Tissue T4 and T3 Concentrations in Animals from Experiment A

\begin{tabular}{|c|c|c|c|c|c|c|c|}
\hline $\begin{array}{c}\text { Group } \\
\text { T4 dose }\end{array}$ & $\begin{array}{l}\mathrm{C} \\
0\end{array}$ & $\begin{array}{c}\text { Tx } \\
0\end{array}$ & $\begin{array}{l}\mathrm{Tx} \\
1.0\end{array}$ & $\begin{array}{l}\mathrm{Tx} \\
2.0\end{array}$ & $\begin{array}{l}\mathrm{Tx} \\
3.0\end{array}$ & $\begin{array}{l}\mathrm{Tx} \\
4.0\end{array}$ & $\begin{array}{l}\mathrm{Tx} \\
8.0\end{array}$ \\
\hline Pl-T4 & $37 \pm 3$ & $<5$ & $49 \pm 3$ & $69 \pm 4$ & $75 \pm 2$ & $95 \pm 6$ & $95 \pm 13$ \\
\hline Pl-T3 & $0.91 \pm 0.05$ & $<0.15$ & $0.93 \pm 0.02$ & $1.18 \pm 0.02$ & $1.44 \pm 0.14$ & $1.81 \pm 0.09$ & $1.98 \pm 0.15$ \\
\hline Pl-TSH & $1.55 \pm 0.23$ & $47.52 \pm 10.77$ & $15.91 \pm 3.33$ & $0.7 \pm 0.11$ & $0.4 \pm 0.01$ & $0.41 \pm 0.03$ & $0.42 \pm 0.02$ \\
\hline Cx-T4 & $1.51 \pm 0.17$ & $0.12 \pm 0.01$ & $2.83 \pm 0.32$ & $4.85 \pm 0.27$ & $4.56 \pm 0.48$ & $5.88 \pm 0.15$ & $6.36 \pm 0.86$ \\
\hline Cx-T3 & $1.92 \pm 0.11$ & $0.10 \pm 0.02$ & $1.77 \pm 0.09$ & $1.73 \pm 0.02$ & $1.80 \pm 0.21$ & $2.15 \pm 0.05$ & $2.23 \pm 0.08$ \\
\hline $\mathrm{Cb}-\mathrm{T} 4$ & $7.43 \pm 0.70$ & $0.16 \pm 0.01$ & $5.99 \pm 1.08$ & $9.02 \pm 1.17$ & $15.81 \pm 2.57$ & $15.32 \pm 1.18$ & $11.48 \pm 0.75$ \\
\hline $\mathrm{Cb}-\mathrm{T} 3$ & $1.63 \pm 0.04$ & $0.13 \pm 0.02$ & $1.44 \pm 0.06$ & $1.88 \pm 0.39$ & $1.88 \pm 0.20$ & $2.30 \pm 0.14$ & $3.25 \pm 0.18$ \\
\hline BAT-T4 & $5.31 \pm 0.43$ & $2.78 \pm 0.34$ & $15.47 \pm 3.84$ & $8.18 \pm 2.50$ & $3.44 \pm 0.43$ & $4.86 \pm 1.28$ & $8.58 \pm 2.62$ \\
\hline BAT-T3 & $1.79 \pm 0.22$ & $0.38 \pm 0.04$ & $2.19 \pm 0.33$ & $1.96 \pm 0.43$ & $1.12 \pm 0.09$ & $1.07 \pm 0.18$ & $1.98 \pm 0.80$ \\
\hline L-T4 & $18.35 \pm 0.81$ & $0.24 \pm 0.02$ & $20.68 \pm 1.83$ & $60.12 \pm 7.58$ & $42.77 \pm 12.70$ & $64.01 \pm 10.99$ & $79.04 \pm 3.83$ \\
\hline L-T3 & $2.81 \pm 0.23$ & $0.07 \pm 0.01$ & $1.32 \pm 0.10$ & $2.87 \pm 0.23$ & $3.62 \pm 0.71$ & $7.71 \pm 0.38$ & $7.71 \pm 0.30$ \\
\hline K-T4 & $24.79 \pm 1.26$ & $0.18 \pm 0.00$ & $24.17 \pm 2.34$ & $41.99 \pm 5.01$ & $58.21 \pm 5.38$ & $51.26 \pm 4.61$ & $59.70 \pm 2.62$ \\
\hline K-T3 & $4.78 \pm 0.50$ & $0.09 \pm 0.01$ & $3.35 \pm 0.04$ & $6.88 \pm 0.95$ & $9.86 \pm 1.14$ & $9.70 \pm 0.73$ & $14.57 \pm 0.98$ \\
\hline Lu-T4 & $6.68 \pm 0.20$ & $0.21 \pm 0.03$ & $8.00 \pm 0.39$ & $12.75 \pm 0.95$ & $11.48 \pm 1.44$ & $9.59 \pm 0.91$ & $18.05 \pm 0.61$ \\
\hline Lu-T3 & $1.84 \pm 0.11$ & $0.10 \pm 0.01$ & $1.21 \pm 0.03$ & $1.94 \pm 0.17$ & $2.87 \pm 0.21$ & $2.55 \pm 0.32$ & $4.39 \pm 0.74$ \\
\hline H-T4 & $5.02 \pm 0.40$ & $0.19 \pm 0.00$ & $6.37 \pm 0.27$ & $9.18 \pm 0.59$ & $9.40 \pm 0.92$ & $10.80 \pm 0.82$ & $14.40 \pm 1.44$ \\
\hline H-T3 & $1.47 \pm 0.04$ & $0.05 \pm 0.00$ & $1.01 \pm 0.06$ & $1.67 \pm 0.30$ & $2.17 \pm 0.20$ & $2.18 \pm 0.04$ & $3.68 \pm 0.60$ \\
\hline $\mathrm{Mu}-\mathrm{T} 4$ & $0.89 \pm 0.07$ & $0.17 \pm 0.00$ & $1.27 \pm 0.06$ & $3.04 \pm 0.32$ & $1.49 \pm 0.15$ & $3.07 \pm 0.18$ & $3.98 \pm 0.15$ \\
\hline Mu-T3 & $0.44 \pm 0.01$ & $0.05 \pm 0.00$ & $0.41 \pm 0.04$ & $0.73 \pm 0.04$ & $0.45 \pm 0.04$ & $1.04 \pm 0.09$ & $1.40 \pm 0.18$ \\
\hline S-T4 & $2.79 \pm 0.23$ & $0.32 \pm 0.04$ & $3.42 \pm 0.20$ & $6.55 \pm 0.29$ & $6.96 \pm 0.91$ & $8.81 \pm 0.76$ & $10.95 \pm 0.66$ \\
\hline S-T3 & $0.76 \pm 0.02$ & $0.15 \pm 0.02$ & $0.58 \pm 0.02$ & $0.95 \pm 0.08$ & $1.03 \pm 0.12$ & $1.52 \pm 0.11$ & $1.72 \pm 0.06$ \\
\hline
\end{tabular}

Experiment A: Mean ( \pm SEM) values of plasma T4 $(\mathrm{ng} / \mathrm{ml}), \mathrm{T} 3(\mathrm{ng} / \mathrm{ml})$, and TSH $(\mathrm{ng} / \mathrm{ml})$, and tissue $\mathrm{T} 4 \mathrm{and} \mathrm{T} 3$ (ng/gram) concentrations in control intact rats $(C)$, in thyroidectomized rats $(T x)$ infused with placebo, and Tx rats infused with T4. The doses are in $\mu \mathrm{g} T 4 / 100$ grams BW per day.

curves (linear, power, inverse, sigmoidal, and logarithmic). The curve fit with the highest coefficient of determination $\left(R^{2}\right)$, degrees of freedom (d.f.), and $F$ statistics, was selected for each tissue. Statistical analyses were performed with the SPSS Base System Software for the Macintosh version 4.0 and SPSS for Windows version 6.0 (SPSS Inc., Chicago, IL).

\section{Results}

Circulating T4, T3, and TSH, and concentrations of T4 and $T 3$ in different tissues as function of the T4 dose

Tables I and II show the circulating T4, T3, and TSH levels, and the tissue $\mathrm{T} 4$ and $\mathrm{T} 3$ concentrations for the different groups of rats from experiments $A$ and $B$, respectively, with the significance of differences versus the respective control group schematically summarized in Table III.

To be able to combine the results from both experiments, and to compare the degree of the changes observed in the plasma with those found in different tissues, the T4, T3, and TSH concentrations in samples from each thyroidectomized rat, and from each thyroidectomized rat on the different $\mathrm{T} 4$ doses, are expressed in figures and further tables as percentages of the mean value corresponding to the group of intact controls, taken as $100 \%$.

Plasma T4, T3, and TSH. Fig. 1 shows changes in their concentrations as a function of the $\mathrm{T} 4$ dose infused into the thyroidectomized rats. Plasma T4 was low in the groups of thyroidectomized rats infused with placebo or with $\mathrm{T} 4$ at doses of 0.2 and $0.4 \mu \mathrm{g} / 100$ grams BW per day, normal in the groups infused with $0.6,0.8$, and $1.0 \mu \mathrm{g} \mathrm{T} 4 / 100$ grams BW per day, and elevated in the groups infused with $1.6,2.0,3.0,4.0$, and $8.0 \mu \mathrm{g}$ T4/100 grams BW per day. On the contrary, plasma T3 only reached normal levels with the doses of 1.0 and $1.6 \mu \mathrm{g}$ $\mathrm{T} 4 / 100$ grams BW per day, remaining low in the rats infused with lower doses of $\mathrm{T} 4$ or placebo, and elevated with higher doses of T4. Plasma TSH was elevated in the rats infused with placebo or T4 at doses from 0.2 to $1.0 \mu \mathrm{g} \mathrm{T} 4 / 100$ grams BW per day, normal in the rats infused with $1.6 \mu \mathrm{g}$ T4/100 grams

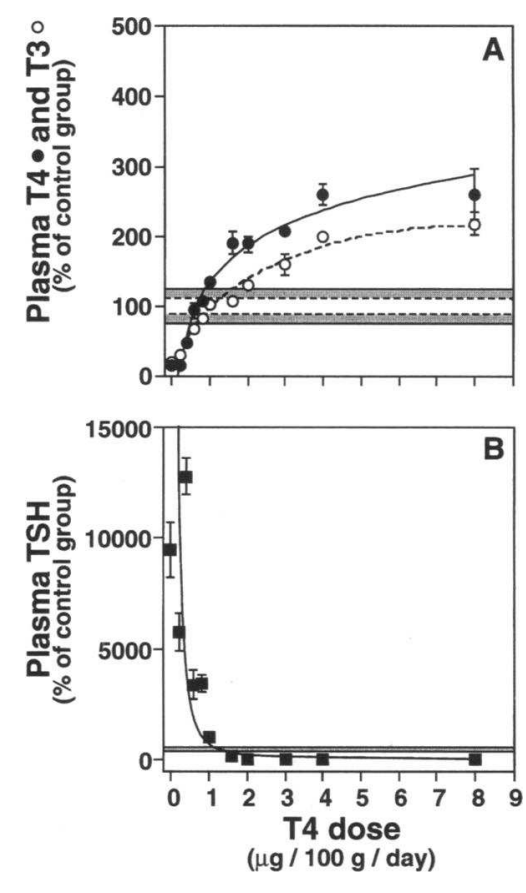

Figure 1. (A) The changes in plasma $\mathrm{T} 4$ and $\mathrm{T} 3$ concentration ( full and empty circles, respectively) of thyroidectomized rats, infused with placebo or $\mathrm{T} 4$, as a function of the dose of T4. Values shown are means $( \pm$ SEM $)$, and are expressed as percentages of the mean value found for control intact animals. The areas enclosed by horizontal lines represent the $95 \%$ confidence intervals of the plasma T4 (full lines, dotted area) or $\mathrm{T} 3$ (dotted lines, white area) of intact control rats. $(B)$ The corresponding changes in circulating TSH, superimposed on those of normal controls (horizontal dotted area). 
Table II. Circulating Concentrations of T4, T3, and TSH, and Tissue T4 and T3 Concentrations in Animals from Experiment B

\begin{tabular}{|c|c|c|c|c|c|c|c|}
\hline $\begin{array}{l}\text { Group } \\
\text { T4 dose }\end{array}$ & $\begin{array}{l}\mathrm{C} \\
0\end{array}$ & $\begin{array}{c}\mathrm{Tx} \\
0\end{array}$ & $\begin{array}{l}\text { Tx } \\
0.2\end{array}$ & $\begin{array}{l}\text { Tx } \\
0.4\end{array}$ & $\begin{array}{l}\text { Tx } \\
0.6\end{array}$ & $\begin{array}{l}\text { Tx } \\
0.8\end{array}$ & $\begin{array}{l}\mathrm{Tx} \\
1.6\end{array}$ \\
\hline Pl-T4 & $35 \pm 4$ & $<5$ & $<5$ & $17 \pm 1$ & $33 \pm 4$ & $38 \pm 2$ & $67 \pm 5$ \\
\hline Pl-T3 & $0.79 \pm 0.09$ & $<0.15$ & $0.22 \pm 0.03$ & $0.36 \pm 0.03$ & $0.52 \pm 0.05$ & $0.64 \pm 0.02$ & $0.84 \pm 0.03$ \\
\hline Pl-TSH & $0.55 \pm 0.01$ & $51.59 \pm 6.65$ & $31.14 \pm 4.67$ & $69.48 \pm 4.32$ & $18.4 \pm 3.52$ & $18.56 \pm 2.16$ & $0.77 \pm 0.17$ \\
\hline Cx-T4 & $4.00 \pm 0.39$ & $0.71 \pm 0.01$ & $0.84 \pm 0.06$ & $1.24 \pm 0.12$ & $1.99 \pm 0.13$ & $2.65 \pm 0.37$ & $6.26 \pm 0.88$ \\
\hline Cx-T3 & $1.93 \pm 0.04$ & $0.19 \pm 0.04$ & $1.27 \pm 0.05$ & $2.13 \pm 0.15$ & $2.11 \pm 0.05$ & $2.07 \pm 0.10$ & $2.34 \pm 0.10$ \\
\hline $\mathrm{Cb}-\mathrm{T} 4$ & $5.05 \pm 0.81$ & $0.51 \pm 0.02$ & $1.23 \pm 0.15$ & $3.29 \pm 0.36$ & $5.93 \pm 0.26$ & $7.60 \pm 0.27$ & $12.89 \pm 1.00$ \\
\hline $\mathrm{Cb}-\mathrm{T} 3$ & $2.14 \pm 0.14$ & $0.13 \pm 0.00$ & $0.85 \pm 0.08$ & $1.59 \pm 0.08$ & $1.74 \pm 0.04$ & $1.94 \pm 0.06$ & $2.14 \pm 0.08$ \\
\hline BAT-T4 & $6.32 \pm 0.66$ & $0.46 \pm 0.05$ & $1.56 \pm 0.21$ & $6.38 \pm 0.48$ & $5.47 \pm 0.73$ & $11.67 \pm 0.90$ & $24.79 \pm 3.25$ \\
\hline BAT-T3 & $3.10 \pm 0.28$ & $0.13 \pm 0.01$ & $1.02 \pm 0.06$ & $1.95 \pm 0.22$ & $2.56 \pm 0.20$ & $3.79 \pm 0.08$ & $2.04 \pm 0.17$ \\
\hline L-T4 & $33.20 \pm 2.36$ & $0.91 \pm 0.20$ & $4.01 \pm 0.62$ & $14.98 \pm 0.31$ & $20.91 \pm 0.51$ & $26.00 \pm 0.77$ & $61.33 \pm 2.51$ \\
\hline L-T3 & $4.69 \pm 0.28$ & $1.60 \pm 0.43$ & $0.91 \pm 0.09$ & $1.93 \pm 0.08$ & $2.21 \pm 0.05$ & $3.00 \pm 0.13$ & $4.66 \pm 0.16$ \\
\hline K-T4 & $18.63 \pm 1.72$ & $0.42 \pm 0.09$ & $2.67 \pm 0.24$ & $6.99 \pm 1.08$ & $11.97 \pm 1.07$ & $13.62 \pm 0.61$ & $31.05 \pm 1.29$ \\
\hline K-T3 & $5.48 \pm 0.37$ & $1.43 \pm 0.19$ & $1.90 \pm 0.27$ & $2.43 \pm 0.16$ & $3.12 \pm 0.20$ & $4.33 \pm 0.34$ & $5.98 \pm 0.09$ \\
\hline Lu-T4 & $7.59 \pm 0.86$ & $0.26 \pm 0.02$ & $1.42 \pm 0.25$ & $3.83 \pm 0.71$ & $6.15 \pm 0.28$ & $8.80 \pm 0.82$ & $14.31 \pm 1.23$ \\
\hline Lu-T3 & $2.95 \pm 0.21$ & $0.08 \pm 0.01$ & $0.71 \pm 0.07$ & $1.28 \pm 0.16$ & $1.39 \pm 0.07$ & $1.82 \pm 0.18$ & $2.24 \pm 0.19$ \\
\hline H-T4 & $4.42 \pm 0.84$ & $0.32 \pm 0.05$ & $0.91 \pm 0.10$ & $1.51 \pm 0.17$ & $3.20 \pm 0.16$ & $5.36 \pm 1.37$ & $5.59 \pm 0.50$ \\
\hline H-T3 & $1.66 \pm 0.04$ & $0.12 \pm 0.01$ & $0.37 \pm 0.03$ & $0.60 \pm 0.07$ & $1.24 \pm 0.06$ & $1.20 \pm 0.07$ & $1.14 \pm 0.13$ \\
\hline $\mathrm{Mu}-\mathrm{T} 4$ & $1.16 \pm 0.18$ & $0.19 \pm 0.02$ & $0.41 \pm 0.03$ & $1.12 \pm 0.05$ & $1.55 \pm 0.21$ & $1.76 \pm 0.11$ & $3.97 \pm 0.13$ \\
\hline Mu-T3 & $0.63 \pm 0.06$ & $0.06 \pm 0.00$ & $0.24 \pm 0.02$ & $0.38 \pm 0.01$ & $0.41 \pm 0.04$ & $0.55 \pm 0.04$ & $0.77 \pm 0.02$ \\
\hline S-T4 & $3.61 \pm 0.43$ & $0.68 \pm 0.09$ & $0.73 \pm 0.12$ & $2.14 \pm 0.26$ & $4.42 \pm 0.34$ & $4.87 \pm 0.22$ & $8.56 \pm 0.69$ \\
\hline S-T3 & $0.89 \pm 0.05$ & $0.16 \pm 0.03$ & $0.32 \pm 0.03$ & $0.48 \pm 0.04$ & $0.73 \pm 0.04$ & $0.84 \pm 0.02$ & $1.38 \pm 0.06$ \\
\hline
\end{tabular}

Experiment B: Mean ( \pm SEM) values of plasma T4 $(\mathrm{ng} / \mathrm{ml}), \mathrm{T} 3(\mathrm{ng} / \mathrm{ml})$ and TSH $(\mathrm{ng} / \mathrm{ml})$, and tissue T4 and T3 (ng/gram) concentrations in control intact rats $(C)$, in thyroidectomized rats $(T x)$ infused with placebo, and $\mathrm{Tx}$ rats infused with $\mathrm{T} 4$. The doses are in $\mu \mathrm{g} \mathrm{T} 4 / 100 \mathrm{grams} \mathrm{BW}$ per day.

BW per day, and low in the animals infused with higher doses. In summary, none of the $10 \mathrm{~T} 4$ doses which we infused, and which ranged from 0.2 to $8.0 \mu \mathrm{g}$ T4/100 grams BW per day, was able to normalize simultaneously plasma T4, T3, and TSH: $\mathrm{T} 4$ and $\mathrm{T} 3$ were normal with the infusion of $1.0 \mu \mathrm{g} \mathrm{T} 4 / 100$ grams BW per day, but TSH remained elevated; with the infusion of $1.6 \mu \mathrm{g} \mathrm{T} 4 / 100$ grams BW per day T3 and TSH were normal, but T4 was elevated. Thus, supraphysiological levels of plasma T4 were needed to normalize plasma TSH.

Tissue T4 and T3. Fig. 2 shows their changes in several tissues as a function of the T4 dose. As may be seen, the degree of increase of T4 and T3 was not the same for all tissues studied. Thus, with the highest dose of T4 that was infused, the concentration of $\mathrm{T} 4$ increased fourfold, or more, in $\mathrm{Cx}, \mathrm{L}, \mathrm{S}$,

Table III. Schematic Representation of Plasma Concentrations of T4, T3, and TSH, and Tissue Levels of T4 and T3, in Thyroidectomized Rats Infused with Different Doses of T4 with Respect to Age- and Sex-matched Controls*

\begin{tabular}{|c|c|c|c|c|c|c|c|c|c|c|c|c|c|c|c|c|c|c|c|c|c|c|c|c|c|c|c|c|c|c|}
\hline \multirow{2}{*}{$\begin{array}{l}\text { Dose of } \mathrm{T}^{\ddagger} \\
(\mu \mathrm{g} / 100 \text { grams } \\
\text { BW per day) }\end{array}$} & \multicolumn{3}{|c|}{0.2} & \multicolumn{3}{|c|}{0.4} & \multicolumn{3}{|c|}{0.6} & \multicolumn{3}{|c|}{0.8} & \multicolumn{3}{|c|}{1.0} & \multicolumn{3}{|c|}{1.6} & \multicolumn{3}{|c|}{2.0} & \multicolumn{3}{|c|}{ 3.0 } & \multicolumn{3}{|c|}{4.0} & \multicolumn{3}{|c|}{8.0} \\
\hline & $\mathrm{T} 4$ & T3 & TSH & T4 & $\mathrm{T} 3$ & TSH & T4 & T3 & TSH & T4 & T3 & TSH & $\mathrm{T} 4$ & T3 & TSH & T4 & $\mathrm{T} 3$ & TSH & T4 & $\mathrm{T} 3$ & TSH & T4 & T3 & TSH & T4 & T3 & TSH & T4 & T3 & TSH \\
\hline Plasma & $=$ & - & 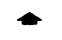 & - & $=$ & - & $=$ & - & - & $=$ & $\infty$ & 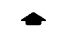 & $=$ & $=$ & . & - & $=$ & $=$ & 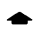 & $\Delta$ & $=$ & 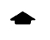 & - & - & - & - & $=$ & - & - & \\
\hline Cerebral cortex & $=$ & $=$ & & $\sigma$ & $=$ & & 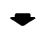 & $=$ & & $=$ & $=$ & & - & $=$ & & - & $\Delta$ & & - & $=$ & & - & $=$ & & - & $=$ & & - & $=$ & \\
\hline Cerebellum & $=$ & - & & $=$ & $\nabla$ & & $=$ & $\varnothing$ & & - & $=$ & & $=$ & $=$ & & - & $=$ & & $=$ & $=$ & & - & $=$ & & - & - & & - & - & \\
\hline BAT & & - & & & $=$ & & & $=$ & & & $=$ & & & $=$ & & & - & & & $=$ & & & $=$ & & & $=$ & & & $=$ & \\
\hline Liver & $=$ & - & & - & $=$ & & $=$ & $=$ & & $\varnothing$ & - & & $=$ & $=$ & & - & $=$ & & - & $=$ & & - & $=$ & & - & - & & - & - & \\
\hline Kidney & $=$ & $=$ & & - & $=$ & & $\Rightarrow$ & - & & $\infty$ & 0 & & $=$ & 0 & & - & $=$ & & - & - & & - & - & & - & - & & - & - & \\
\hline Lung & - & - & & - & - & & $=$ & - & & $=$ & - & & $=$ & $=$ & & - & 0 & & - & $=$ & & - & - & & - & - & & - & - & \\
\hline Heart & - & $=$ & & $=$ & $=$ & & $=$ & $\infty$ & & $=$ & $\infty$ & & $=$ & - & & $=$ & - & & - & $=$ & & - & - & & - & - & & - & - & \\
\hline Muscle & $=$ & $=$ & & $=$ & $=$ & & $=$ & - & & - & $=$ & & - & $=$ & & - & $\Delta$ & & - & - & & - & $=$ & & - & - & & - & - & \\
\hline Spleen & - & $=$ & & $=$ & $=$ & & $=$ & $\infty$ & & $=$ & $=$ & & $=$ & $\sigma$ & & 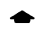 & - & & - & $=$ & & - & - & & - & - & & - & - & \\
\hline
\end{tabular}

* The symbols represent the comparison of the mean values of the T4-infused rats with control rats infused with placebo: $=$ indicates that there were no statistically significant differences; - identifies low levels as compared to controls, with at least $P<0.05$; - identifies elevated levels as compared to controls, with at least $P<0.05$. An open arrow ( $\sigma$ or $\sigma$ ) indicates that, although statistically significant, the change with respect to controls was relatively small, within the $\pm 30 \%$ of the mean of the control group. ${ }^{\ddagger}$ The bold numbers indicate the doses of T4 used in experiment A. 


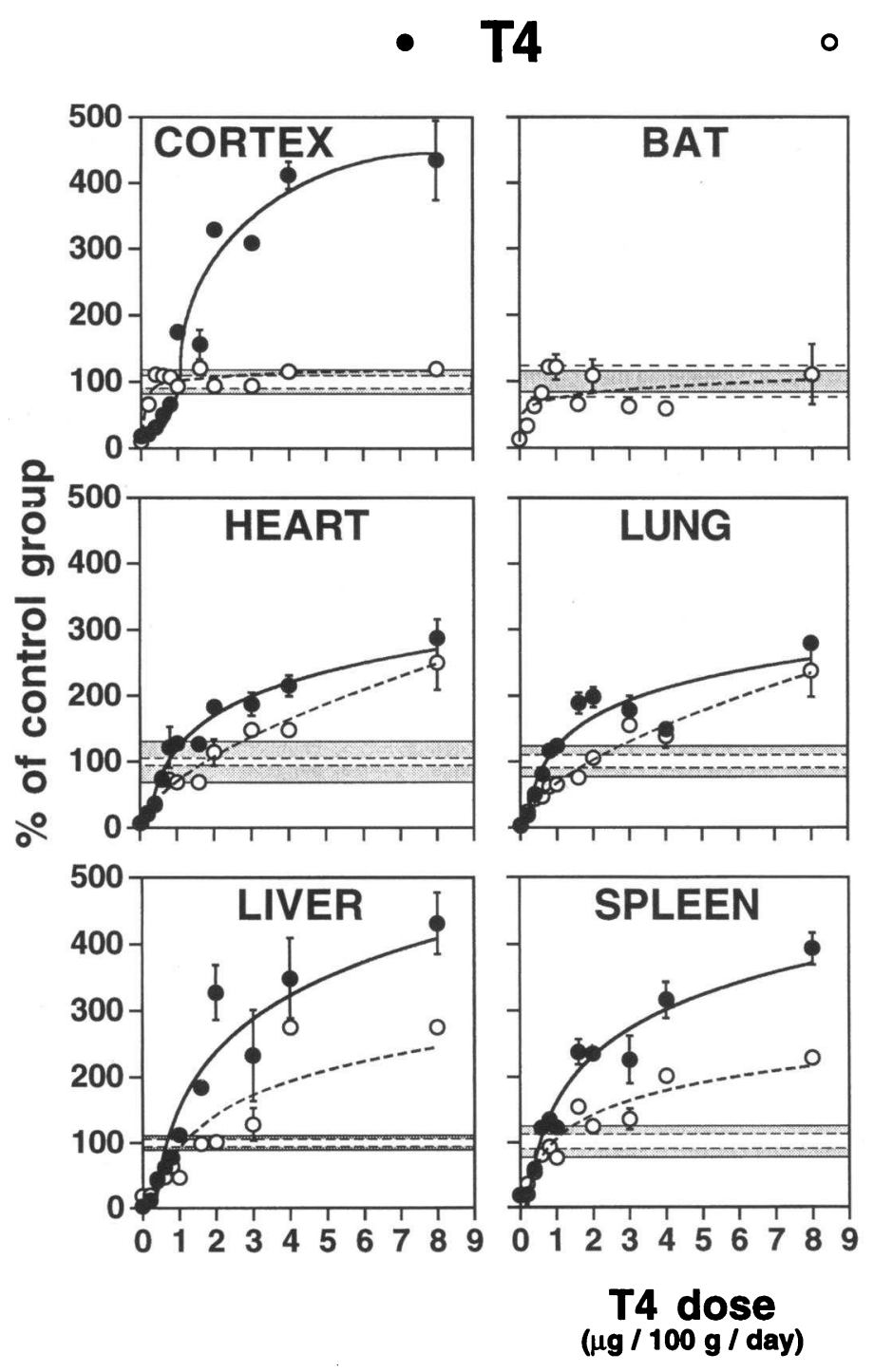

T3
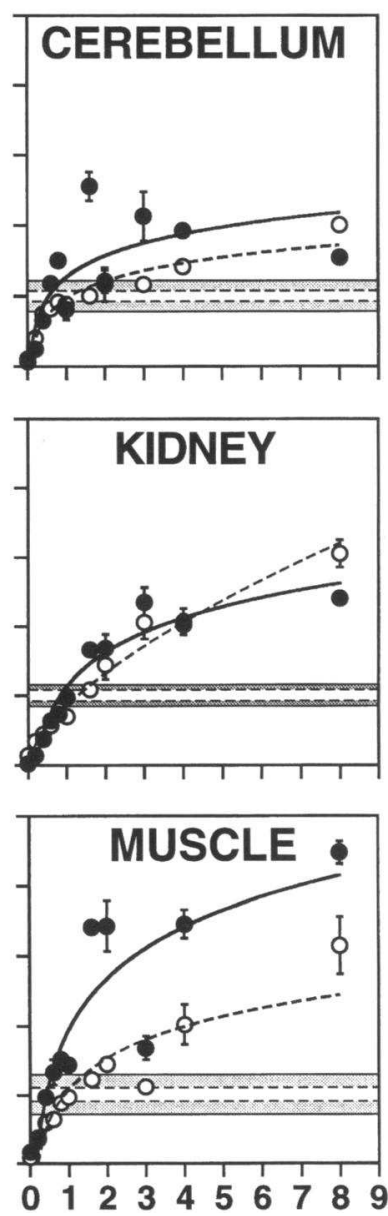

Figure 2. The changes in concentrations of T4 (full circles) and T3 (empty circles) in different tissues of thyroidectomized rats, infused with placebo or T4 are shown as function of the T4 dose. Expression of data and meaning of dotted and white areas is the same as indicated in the legend to Fig. $1 A$. The concentrations of $\mathrm{T} 4$ in BAT of T4-infused animals are not shown, for reasons outlined in the text. and $\mathrm{Mu}$, but only two- to threefold in BAT, $\mathrm{Cb}, \mathrm{Lu}, \mathrm{H}$, and $\mathrm{K}$. The same occurred with the degree of increase in T3, which was different for different tissues.

Moreover, the dose needed to ensure a normal concentration of each iodothyronine (see Table III) was not the same for all tissues studied. In general, normal tissue $\mathrm{T} 4$ levels were achieved with lower T4 doses than the ones needed to normalize tissue T3. Conversely, supraphysiological T4 levels were needed to normalize T3 levels in most tissues. In several tissues T3 only became normal when normal or supraphysiological plasma T3 concentrations were reached.

In most tissues, normal concentrations of $\mathrm{T} 4$ are not reached until the dose of $\mathrm{T} 4$ is sufficient to result in normal circulating T4. Thus, the lowest of such doses, namely $0.6 \mu \mathrm{g} \mathrm{T} 4 / 100$ grams BW per day, resulted in normal $\mathrm{T} 4$ concentrations in the heart, lung, spleen, and cerebellum, although higher doses were needed to normalize liver and kidney T4. An interesting exception is the skeletal muscle, where T4 was already normal in the thyroidectomized rats infused with only $0.4 \mu \mathrm{g} \mathrm{T} 4 / 100$ grams BW per day, a dose which is insufficient to normalize circulating T4.

The minimal dose of $\mathrm{T} 4$ which resulted both in normal circulating $\mathrm{T} 4$ and $\mathrm{T} 3$, namely $1.0 \mu \mathrm{g} \mathrm{T} 4 / 100$ grams $\mathrm{BW}$ per day, was insufficient to normalize the concentration of $\mathrm{T} 3$ in most tissues, which required $\mathrm{T} 4$ doses resulting in supraphysiological circulating T4. Notable exceptions are, however, the $\mathrm{Cx}$, $\mathrm{BAT}$, and $\mathrm{Cb}$, tissues which showed a remarkable degree of independence from plasma T4 and T3 levels: normal or near normal T3 concentrations were found over a wide range of T4 doses. Cerebral cortex T3 concentrations were low in thyroidectomized rats infused with placebo or $0.2 \mu \mathrm{g} \mathrm{T} 4 / 100$ grams BW per day, but presented normal $\mathrm{T} 3$ levels with doses ranging from 0.4 to $8.0 \mu \mathrm{g} \mathrm{T} 4 / 100$ grams BW per day (with the exception of mildly elevated levels in the group of thyroidectomized rats infused with $1.6 \mu \mathrm{g} \mathrm{T} 4 / 100$ grams BW per day). This excellent T3 homeostasis was independent of plasma T4 and T3 levels, and of T4 levels in the Cx, which were low with 0.2 to $0.8 \mu \mathrm{g}$ $\mathrm{T} 4 / 100$ grams BW per day, and elevated with doses of 1.0 to 8.0 $\mu \mathrm{g}$ T4/100 grams BW per day. Similar results were observed in BAT and, to a lesser degree, in Cb.

Triiodothyronine concentrations in BAT were low in rats infused with placebo or with 0.2 and $0.4 \mu \mathrm{g} / 100$ grams BW and normal with most of the doses ranging from 0.6 to $8.0 \mu \mathrm{g}$ T4/100 grams BW per day. Thyroxine concentrations in BAT were low in thyroidectomized rats infused with placebo, and highly variable in the T4-infused groups, both between and 


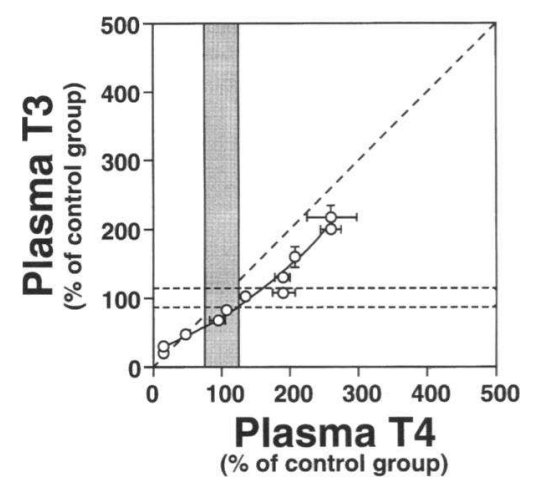

among the different groups. These $\mathrm{T} 4$ values might be questioned because of the proximity of the interscapular BAT pads to the site where the osmotic pump is implanted, and from which it is only separated by an easily punctured thin layer of connective tissue. Although care was taken at autopsy to avoid contact between the BAT pads and fluid surrounding the T4containing pumps, some external contamination with $\mathrm{T} 4$ might have occurred. For this reason T4 values in BAT are not shown in further figures and tables.

Cerebellar T3 was low in rats infused with placebo, 0.2, 0.4 , and $0.6 \mu \mathrm{g} \mathrm{T} 4 / 100$ grams BW per day, normal with 0.8 to $3.0 \mu \mathrm{g}$ T4/100 grams BW per day, and elevated with 4.0 and $8.0 \mu \mathrm{g} \mathrm{T} 4 / 100$ grams BW per day. Cerebellar T4 levels were low in rats infused with placebo, 0.2 , and $0.4 \mu \mathrm{g} / 100$ grams BW and day, normal with $0.6,1.0$, and $2.0 \mu \mathrm{g} / 100$ grams BW and day, and elevated with $0.8,1.6,3.0$, and $8.0 \mu \mathrm{g} \mathrm{T} 4 / 100$ grams BW per day.

\section{Concentrations of T4 and T3 in different tissues as function of circulating T4 and T3}

It appeared interesting to define the relationship between circulating and tissue concentrations of T4 and T3, irrespective of the dose of T4. Fig. 3 shows changes in plasma T3 as a function of plasma T4. Plasma T4 levels varied, for thyroidectomized rats on placebo and those infused with the highest $\mathrm{T} 4$ dose, between 14 (limit of detection) and $352 \%$ of the mean $\mathrm{T} 4$ value for control rats, and circulating T3 varied between 16 and $245 \%$ of the mean T3 value of the controls. The relationship is not the linear one expected if the changes in circulating T3 were of the same magnitude as those of T4. The closest fit to the individual paired plasma data was found for the power function: $\mathrm{T} 3=2.62 \cdot \mathrm{T} 4^{0.75}$, (with d.f. $=49, \mathrm{R}^{2}=0.96$, and $P<0.001$ ). As indicated before, plasma T3 increases less than T4 in the hypothyroid range, and supraphysiological plasma $\mathrm{T} 4$ levels have to be reached for normalization of plasma T3.

The concentration of $\mathrm{T} 4$ or $\mathrm{T} 3$ in each tissue was paired against the corresponding circulating iodothyronine levels. The best curve fit within the present range of plasma $\mathrm{T} 4$ and $\mathrm{T} 3$ concentrations was determined using the individual paired data from both experiments. Fig. 4 shows some examples of the type of interrelationships which were found, namely the changes in $\mathrm{T} 4$ and $\mathrm{T} 3$ of $\mathrm{Cx}, \mathrm{Cb}, \mathrm{K}$, and $\mathrm{S}$, as functions of the circulating T4 and T3 levels, and not, as in Fig. 2, as functions of the infused dose of T4. These curves and those corresponding to other tissues are derived from the equations summarized in
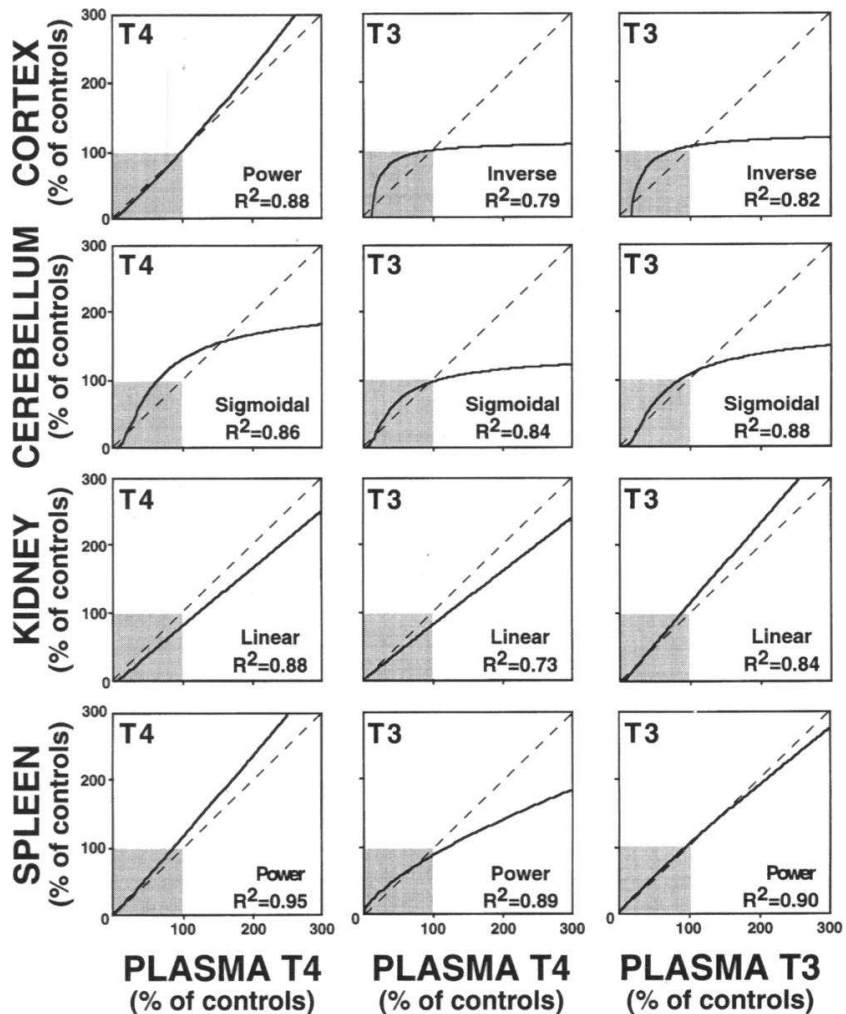

Figure 4. Different examples are shown of the best-fit curves obtained for the concentrations of T3 or T4 in tissues, as a function of circulating T4 or T3 levels. Data correspond to the formulas summarized in Tables AI-AIII. The dotted square inset separates the values below and above those of control intact rats. The thin diagonal line corresponds to the relationship which would be found if changes in circulating T4 or T3 were accompanied by changes of equal intensity in the tissues.

Tables AI-AIII of the Appendix. The type of curve fitted to the individual data, the corresponding equation, as well as the d.f., $\mathrm{R}^{2}$, and $F$ statistics are shown in these tables. Most of the curves fitting the tissue T4 or T3 concentrations to the circulating T4 and T3 levels are not linear, although the exponent in the power functions ranged from 0.68 to 1.66 , and the curves are almost linear (an exponent $=1.0$ corresponds to a linear function).

It is evident that neither plasma T4 nor plasma T3 levels alone permit prediction of the degree of change in $\mathrm{T} 4$ and $\mathrm{T} 3$ concentrations in tissues: not only are the tissue to plasma T4 and $\mathrm{T} 3$ ratios different for different tissues, but they may also change for a single tissue as a function of the plasma iodothyronine level.

Using the information summarized in Tables AI-AIII, we have calculated the T4 and T3 levels which would be expected in different tissues when circulating $\mathrm{T} 4$ and $\mathrm{T} 3$ are comparable to those of intact controls. These are shown in Fig. 5, A-1-A3 , superimposed on the normal range of $\mathrm{T} 4$ and $\mathrm{T} 3$ concentrations for the corresponding tissue.

Fig. $5 A-2$ illustrates the finding that a normal plasma T4 level concentration does not ensure that $\mathrm{T} 3$ is normal in tissues, with the notable exception of $\mathrm{Cx}$ and $\mathrm{Cb}$, and possibly $\mathrm{K}, \mathrm{Mu}$, and S. Fig. 5 A-3 summarizes the finding that the concentration of T3 may still be low in some tissues, such as Lu and BAT, even when infusion of the thyroidectomized rats with T4 has resulted in normal plasma T3. It would appear that a normal 

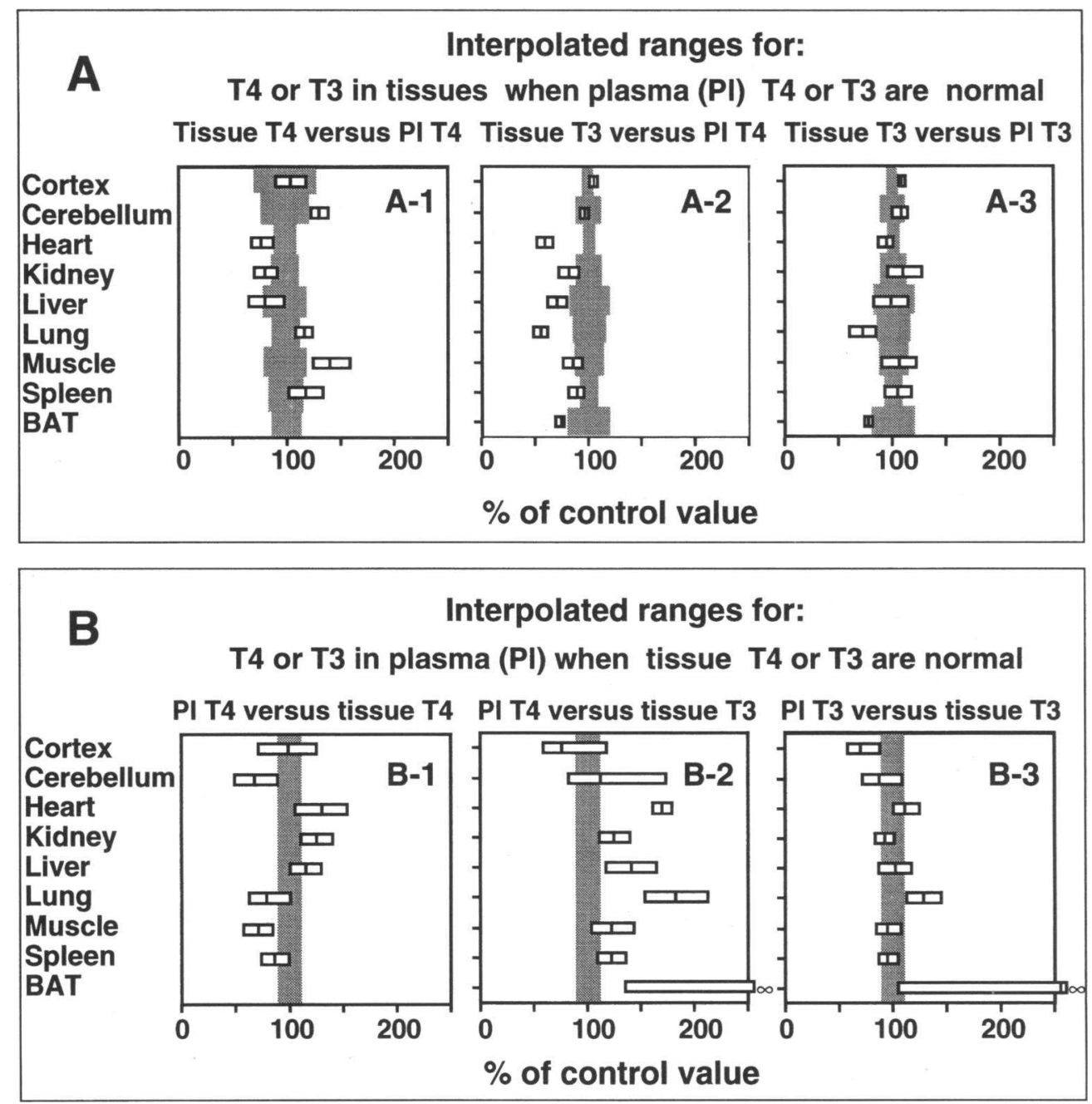

Figure 5. (A-1 to $A-3)$ The calculated values of T4 or T3 concentrations (horizontal bars) which would be expected in different tissues of thyroidectomized, T4-infused rats when their circulating $\mathrm{T} 4$ or $\mathrm{T} 3$ levels are the same as those measured in the plasma of intact control rats. The values shown in the different panels are those interpolated from the corresponding equation, as given in $\mathrm{Ta}-$ bles AI-AIII of the Appendix. The tissue $\mathrm{T} 4$ or $\mathrm{T} 3$ concentration which corresponds to the mean control plasma value is shown as a vertical line inside the bar, which extends laterally to the interpolated values corresponding to the lower and upper $95 \%$ confidence intervals (mean $\pm t \cdot$ SEM) of the control plasma values. The shaded area behind the bars corresponds to the mean and $95 \%$ confidence intervals of the tissue T4 or $\mathrm{T} 3$ concentrations, as measured in intact control rats. $(B-1$ to $B-3)$ The calculated values of the circulating $\mathrm{T} 4$ or $\mathrm{T} 3$ concentrations (horizontal bars) which would be needed for the T4 or T3 levels of thyroidectomized, T4-infused rats to reach normal control values in different tissues. The values shown are those interpolated from the corresponding equation, as given in Tables AI-AIII. The plasma $\mathrm{T} 4$ or $\mathrm{T} 3$ concentration which corresponds to the mean control tissue value is shown as a vertical line inside the bar, which extends laterally to the interpolated values corresponding to the lower and upper $95 \%$ confidence intervals (mean $\pm t \cdot \mathrm{SEM}$ ) of the tissue levels found in the normal controls. The shaded area behind the bars corresponds to the mean and $95 \%$ confidence intervals of the plasma $\mathrm{T} 4$ or $\mathrm{T} 3$ concentrations, as measured in intact control rats. All concentrations are expressed as percentages of the mean control value.

circulating T4 level (Fig. 5 A-1) does not necessarily ensure that $\mathrm{T} 4$ is normal in all tissues: $\mathrm{T} 4$ in $\mathrm{Mu}$ and $\mathrm{Cb}$ are higher than expected from plasma $\mathrm{T} 4$, whereas $\mathrm{T} 4$ tends to be low in $H$, and possibly $K$ and $L$.

Using the same information summarized in Tables AI-AIII we also calculated the inverse, namely, which circulating T4 and T3 levels would have to be reached to ensure that the T4 and T3 values in each tissue are comparable to those of normal control rats. The results are shown in the three panels of Fig. $5 B$, superimposed on the range of normal plasma T4 or T3 concentrations. Fig. $5, B-1-B-3$ stress the unique homeostasis of cerebral T3, which is normal even with plasma T4 and T3 levels which are clearly in a hypothyroid range. On the contrary, normalization of lung T3 in the thyroidectomized, T4-infused rats requires supraphysiological circulating T3. For BAT, the degree of fit of the data by the equations shown in Tables AI and AII of the Appendix was poorer than for other tissues studied here. Despite this, the interpolated values shown in the lower panels of Fig. 5 indicate that T3 did not increase in BAT above the normal range even at the highest plasma $\mathrm{T} 4$ and $\mathrm{T} 3$ levels attained in the present study, namely 3.5 and 2.5 times the mean control values, respectively.

\section{Iodothyronine deiodinase activities}

Liver 5'D-I activity decreased from controls values of $52 \pm 4$ to $16 \pm 12 \mathrm{pmol} \mathrm{I}^{-} / \mathrm{min}$ per $\mathrm{mg}$ protein in the placebo-infused thyroidectomized rats, and increased towards normal activities in the thyroidectomized rats on 1.0 or $1.6 \mu \mathrm{g} \mathrm{T} 4 / 100$ gram BW per day. Liver 5 ' D-I activity further increased with the higher T4 doses, up to 3.5-fold normal values with the dose of $8.0 \mu \mathrm{g}$ $\mathrm{T} 4 / 100$ gram BW per day.

Lung 5 ' D-I activity also decreased from controls values of $557 \pm 17$ to $144 \pm 9 \mathrm{fmol} \mathrm{I}^{-} / \mathrm{h}$ per $\mathrm{mg}$ protein in the placeboinfused thyroidectomized rats. Activities increased in T4-infused thyroidectomized rats and were within the normal range in those infused with 1.0 to $4.0 \mu \mathrm{g} \mathrm{T} 4 / 100$ gram BW per day. Activities increased twofold in the rats receiving $8.0 \mu \mathrm{g} \mathrm{T} 4 /$ 100 gram BW per day.

Cerebral cortex 5'D-II markedly increased in the thyroidectomized rats to $209 \pm 14 \mathrm{fmol} \mathrm{I-/h}$ per $\mathrm{mg}$ protein, as compared to $33 \pm 2 \mathrm{fmol} \mathrm{I}^{-} / \mathrm{h}$ per $\mathrm{mg}$ protein in controls animals. The activity of this enzyme decreased when $\mathrm{T} 4$ was infused, normal values being found in the thyroidectomized rats infused with 0.6 to $3.0 \mu \mathrm{g} \mathrm{T} 4 / 100$ gram BW per day, and decreased to $6.3 \pm 0.3 \mathrm{fmol} \mathrm{I} I^{-} / \mathrm{h}$ per $\mathrm{mg}$ protein in the thyroidectomized rats 
on 4.0 and $8.0 \mu \mathrm{g} \mathrm{T} 4 / 100$ gram BW per day. The activity of the inner-ring $5 \mathrm{D}$-III was $2,022 \pm 473 \mathrm{fmol} \mathrm{I}^{-} / \mathrm{h}$ per $\mathrm{mg}$ protein in $\mathrm{Cx}$ of the control rats. No statistically significant changes which were reproducible in both experiments were observed in the thyroidectomized rats on placebo or $\mathrm{T} 4$ infusion.

\section{Discussion}

The experimental design. The aim of a hormonal replacement therapy is to ensure an adequate supply of the missing hormone in a manner which mimics the normal supply as closely as possible, and results in normal biological effects, both qualitatively and quantitatively. When the thyroid gland is absent or not capable of synthesizing or secreting $\mathrm{T} 4$ and $\mathrm{T} 3$, treatment with T4 is preferred over T3 because it is the main secretory product of the gland and generates T3 in many tissues, some of which are a source of systemic T3 distributed throughout the body by the bloodstream. The mean residence time of $\mathrm{T} 4$ in

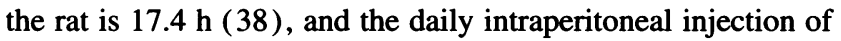
the replacement dose in thyroidectomized animals is accompanied by wide daily fluctuations of the plasma and tissue concentrations of both T4 and T3 (39), as well as fluctuations of a biological end-point of action, such as circulating TSH (40). To avoid this the thyroidectomized rats of the present study have received a constant subcutaneous infusion of $\mathrm{T} 4$, administered using osmotic minipumps, which do not require restraint of the animals, thus allowing free access to food and water. The period of infusion was 12 or $13 \mathrm{~d}$, which is 17 to 22 times the mean residence time of $\mathrm{T} 4$ in adult rats. Previous studies by others $(16,17)$ have shown that adult rats on a constant infusion of radiolabeled T4 are in equilibrium by 6 (euthyroid rats) or 8 (hypothyroid rats) $\mathrm{d}$ of infusion, when the amounts of labeled metabolites excreted daily into the feces and urine become constant and their sum is equivalent to the amount of radioactivity infused daily. In the present study infusion of T4 was extended well beyond this minimum period. Obviously, with this mode of administration diurnal rhythms of circulating T4 and T3, which might be dependent on the circadian variations in TSH (41), would be abolished. Those rhythms which are caused by intracellular events, such as those described for deiodinase activities in several areas of the rat brain (42) or the pineal gland (43) might, however, still be operative.

Maintenance of euthyroidism in tissues. The aim of the present study was to test directly whether, or not, a hypothyroid rat receiving $\mathrm{T} 4$ alone is provided with the necessary regulatory mechanisms to compensate for the lack of thyroidal secretion of T3, a minor source of T3 available to tissues, and thus ensure euthyroidism of all tissues simultaneously. There might be several criteria for defining euthyroidism, or normal thyroid status, of a tissue. One criterion might be that the biological effects of thyroid hormones are the same as in tissues from normal animals, both qualitatively and quantitatively, another that normal concentrations of thyroid hormone are provided to the tissue. The latter criterion assumes that normalization of the iodothyronine content of the tissue would be followed by normalization of the biological effects. It is at present very difficult to apply the first of these two criteria, because of the paucity of biological end-points which we can attribute to direct local effects of the thyroid hormones in different tissues.

It is therefore necessary to rely on the second criterion for euthyroidism, which encloses two possibilities, namely, $(a)$ that both T4 and T3 have to be normal, or $(b)$ that it is enough to ensure normal $\mathrm{T} 3$ concentrations to elicit quantitatively and qualitatively normal biological end-points.

It is evident from the present results that possibility $(a)$ is not met, as the administration of T4 alone to thyroidectomized rats does not result in both normal T4 and T3 simultaneously in all tissues at any of the 10 doses tested. It is also highly unlikely that this would have been achieved with an intermediate dose, possibly between 1.0 and $1.6 \mu \mathrm{g} \mathrm{T} 4 / 100$ gram BW per day. The first of these two doses results in normal circulating T4 and T3, but plasma TSH is still elevated, and T3 low in most tissues. The second of these doses results in high plasma $\mathrm{T} 4$, and normal plasma T3 and TSH, but at the expense of excessive concentrations of $\mathrm{T} 4$ in practically all tissues studied. Even so, T3 may still be low in some tissues. The interpolated values calculated from the curves best fitting the individual data also support the conclusion that infusion of T4 alone, even at doses which were not tested in the present study, is inadequate to normalize tissue $\mathrm{T} 4$ and $\mathrm{T} 3$.

The second possibility, namely that it ought to be sufficient to maintain euthyroidism by normalizing tissue T3 levels reflects the prevailing consensus that this ought to ensure normal $\mathrm{T} 3$ receptor occupancy and, as a consequence, normal biological effects. This concept includes several assumptions, namely, that T4 per se does not exert any biological effect, that all thyroid hormone action is exerted through nuclear thyroid hormone receptors, and that the $\mathrm{T} 3$ bound to the receptor is derived from a single compartment, which does not differentiate between T3 derived from plasma or generated locally in the tissue from T4. Extranuclear effects of T4 have, however, been described (44). Moreover, T4 might contribute to nuclear thyroid hormone receptor occupancy, although to a much lesser degree than T3 (45). If the amount of available T3 is insufficient, T4 occupies the receptor, and exerts a biological effect (46). It has also been reported for the rat liver that plasma-derived T3 and T3 generated locally from $\mathrm{T} 4$ are in different compartments with respect to nuclear receptor binding: practically all of the nuclear T3 appears to be plasma derived (18).

Even if these possibilities are disregarded and normalization of tissue T3 is considered as an adequate criterion to assess tissue euthyroidism, it is clear from the present results that a normal thyroid status is not achieved simultaneously for all tissues when T4 alone is infused. Lung and BAT T3 were still low when plasma T3 was normal. Normal T3 concentrations in many tissues required either supraphysiological concentrations of T4 in the tissue, elevated activities of iodothyronine deiodinases, or both. We do not know if a long-term adverse effect might result from high intracellular T4 concentrations, or from the permanent stimulation of the compensatory mechanisms, which would increase extracellular formation of T3 from T4. The continuous increase in TSH secretion needed to ensure normal plasma T4 in subclinical hypothyroidism is considered undesirable, and substitution therapy to avoid chronic pituitary overstimulation is often recommended (47).

Compensatory mechanisms. Present results confirm for normal adult female rats the tight homeostasis of $\mathrm{T} 3$ concentrations in the $\mathrm{Cx}$ when $\mathrm{T} 4$ is provided to the hypothyroid animal, already described for the rat fetus (22) and adult pregnant rat (48). Cerebral cortex T3 remained within normal limits over a 20 -fold increase in the T4 infusion doses, namely from 0.4 to $8.0 \mu \mathrm{g} \mathrm{T} 4 / 100$ gram BW per day. Normalization of $\mathrm{T} 3$ is achieved in the $\mathrm{Cx}$ when circulating $\mathrm{T} 4$ is half that of normal control animals, and T4 in the $\mathrm{Cx}$ is one-third. This finding is in conceptual agreement with the marked increase in cerebral 
cortex 5'D-II activity of hypothyroid rats (49), as measured in vitro, and confirmed in the present study. The changes of cerebral cortex 5'D-II activity do not, however, appear to offer an adequate explanation for the maintenance of cerebral cortex $\mathrm{T} 3$ homeostasis in rats infused with very high doses of $\mathrm{T} 4$, which resulted in supraphysiological cerebral cortex T4, plasma $\mathrm{T} 4$, and plasma T3 levels. It seems unlikely that the slight inhibition of $5^{\prime} \mathrm{D}-\mathrm{II}$, which was only observed for the animals on the two highest doses of $\mathrm{T} 4$, would be enough to counteract the very marked increase in the concentration of $\mathrm{T} 4$ in the $\mathrm{Cx}$. We also did not find a systematic increase in 5D-III activity, which would contribute to cerebral cortex T3 homeostasis by enhancing both the degradation of $\mathrm{T} 4$ to $\mathrm{rT} 3$ and the deiodination of T3. Obviously, conditions prevailing in vivo might have been superseded by those used for the enzyme assay in vitro. Even if 5D-III activity remained unchanged, the amount of rT3 generated by inner-ring deiodination of $\mathrm{T} 4$ would increase with increasing amounts of available substrate. Reverse $\mathrm{T} 3$ is a potent reversible inhibitor of $5^{\prime} \mathrm{D}$-II (50) and might locally reach inhibitory concentrations in vivo. Other possible mechanisms contributing to maintenance of cerebral cortex T3 homeostasis might involve changes in the availability of endogenous enzyme cofactors, as described for the liver of fasting rats (51), in the rates of uptake and/or exit of the iodothyronines (26), or in nondeiodinative pathways of iodothyronine metabolism (25). Regarding the latter, sulfation of T4 and T3 leads to the formation of the sulfo-conjugates, which greatly enhances their innerring and outer-ring deiodination, both sulfo-conjugates being much better substrates for the selenocisteine-containing 5 ' D-I than the parent iodothyronine $(52,53)$. Sulfation may thus be an important metabolic pathway for the deiodinative clearance of T4 and T3. Sulfotransferase activity is not only high in liver and kidney, but also in the brain $(54,55)$. The importance of this pathway for the maintenance of T3 homeostasis in the Cx is, however, uncertain, as T3S is not a good substrate for 5DIII $(52,53)$, and we did not detect appreciable $5^{\prime} \mathrm{D}-\mathrm{I}$ activity in $\mathrm{Cx}, \mathrm{Cb}$, and BAT. This is in conceptual agreement with the finding that brain microsomes appear to metabolize T3S poorly, and less rapidly than T3 (55), contrary to findings in the liver. Moreover, rat-cultured astrocytes do not sulfate T3, but only the deiodination products of T3 (56). This metabolic pathway might favor the release of iodothyronine metabolites into the circulation. To our knowledge, there is no information regarding formation of T3S by other cells originating from the brain. Another possibility is that the sigmoidal curve for T3 in the cortex and cerebellum is mainly determined by the blood-brain barrier.

Liver 5 ' D-I plays an important role in the generation of T3 and $\mathrm{T} 4$, and the $\mathrm{L}$ is an important source of systemic T3. The changes in the activity of liver $5^{\prime} \mathrm{D}-\mathrm{I}$ measured in the present study agree with those expected from previous investigations: activity decreases in the thyroidectomized rat and then increases towards normal values, that are not reached until liver and plasma T3 are normal and plasma and liver T4 are increased approximately twofold. In animals with normal circulating T4 and T3 the concentrations of the latter iodothyronine are lower than normal in both $\mathrm{P} 1$ and $\mathrm{L}$. Thus, in hypothyroid conditions, the activity of liver 5'D-I does not appear to contribute to the normalization of plasma-derived $\mathrm{T} 3$ in other tissues. This decreased activity of liver 5'D-I would have a T4-sparing effect and might contribute to the normalization of locally generated T3 in tissues with important local production of $\mathrm{T} 3$ from $\mathrm{T} 4$, such as $\mathrm{Cx}$.

Normalization of $\mathrm{T} 3$ concentrations in $\mathrm{Lu}$ required even higher infusion doses of T4 than normalization of T3 in L. Triiodothyronine in Lu was lower than normal even when normal plasma T3 levels were reached. The measured changes in lung 5 'D-I activity do not afford an explanation for this finding, unless locally generated $\mathrm{T} 3$ is rapidly exported into the circulation. The findings for BAT T3 were similar to those for lung T3, inasmuch as BAT T3 reached normal values when plasma T3 was higher than normal. This could be in agreement with the reported finding that BAT represents and important source of systemic T3 $(23,24)$.

An unexpected finding was that skeletal muscle T4 became normal in rats on a T4 dose which was insufficient to ensure normal plasma $\mathrm{T} 4$, and became higher than normal in animals with normal circulating T4. Skeletal muscle T3 was also normal in animals with low circulating T3 levels, but with higher than normal concentrations of $\mathrm{T} 4$ in the tissue. Local conversion of $\mathrm{T} 4$ to $\mathrm{T} 3$ generates a very minor proportion of $\mathrm{T} 3$ in thigh muscle of hypothyroid rats (1.5-3.7\%) and none in euthyroid animals (16), and does not afford an explanation for the latter finding.

In summary, when T4 alone is administered as replacement therapy to thyroidectomized rats, compensatory regulatory mechanisms are unable to provide both normal T4 and T3 concentrations simultaneously in plasma and all tissues. They are also inadequate to at least ensure normal concentrations of T3 in all tissues, even at the expense of excessive T4 concentrations. The dose of T4 needed to normalize thyroid hormone concentrations is different for each tissue, thus pointing to the existence of tissue-specific regulatory mechanisms. Of the tissues studied, $\mathrm{Cx}$ showed a very efficient homeostasis of its $\mathrm{T} 3$ concentrations, providing metabolic protection of this organ against wide changes in thyroid hormone availability.

The infusion of T3 to thyroidectomized rats is also inadequate to ensure normal T3 levels simultaneously in plasma and all tissues (57), whereas preliminary data show that the combined infusion of $\mathrm{T} 4$ and $\mathrm{T} 3$, in a molar ratio similar to that of the thyroidal production, does ensure both normal T4 and T3 in all tissues (58).

Possible clinical implications. The possibility that the present findings in the rat might also be relevant for humans raises questions regarding the current treatment of hypothyroidism with $\mathrm{T} 4$ alone as replacement therapy. There are differences between our experimental model and thyroid replacement therapy in humans. The usual clinical practice entails the oral administration of a single daily dose of $\mathrm{T} 4$. We have preferred delivery of $\mathrm{T} 4$ by a continuous subcutaneous infusion of $\mathrm{T} 4$, to avoid marked daily fluctuations in circulating thyroid hormone levels. The differences between these two types of delivery, however, might not be very great if we consider the mean residence time for $\mathrm{T} 4$ in both species, namely 310 and $17.4 \mathrm{~h}$ in humans and rats, respectively (40). When T4 is given daily, the patient receives 13 doses within the period of mean T4 residence time; fluctuations of serum $\mathrm{T} 4$ are likely to be buffered. This might be roughly equivalent in the rat to 13 doses during a 17.4-h period, which may be considered almost equivalent to constant infusion. The 12-13-d infusion period is several days longer than the minimum time needed to achieve a steady state situation in hypothyroid rats $(16,17)$. If we again take the mean residence time in both species as a plausible basis for comparisons, a 12-d infusion period in the rat would be equivalent to 16.6 times the mean T4 residence time; this would be roughly equivalent to $5,146 \mathrm{~h}$ in $\operatorname{man}(16.6 \cdot 310 \mathrm{~h})$, or $7 \mathrm{mo}$ of treatment. This is usually considered adequate to achieve stable thyroid hormone concentrations (27). 
The relative importance of thyroidal $\mathrm{T} 3$ secretion versus $\mathrm{T} 3$ generation from T4 is likely to be greater in rats than humans, as the molar ratio of $\mathrm{T} 4$ to $\mathrm{T} 3$ in the respective thyroidal secretion is $\sim 6: 1(2-5)$, and 14:1 (1). This might represent an important difference between the present experimental model and the situation in patients, as in humans the thyroidal secretion of T3 might be more easily replaced by $\mathrm{T} 3$ generated from $\mathrm{T} 4$. On the other hand, we have practically no information regarding the compensatory mechanisms responding to hypo- and hyperthyroidism in humans, or the concentrations of $\mathrm{T} 4$ and $\mathrm{T} 3$ in tissues of normal people or T4-treated patients. There are data, however, which strongly suggest that present main conclusions are relevant for patients, inasmuch as peripheral compensatory mechanisms do not provide adequate circulating levels of both $\mathrm{T} 4$ and T3 in hypothyroid patients on T4: for similar plasma levels of T3 and TSH (59) patients on T4 replacement therapy present higher circulating $\mathrm{T} 4$ than normal controls. This situation is the same we have found in the present experimental study, and suggests that similarities may well exist as regards tissue concentrations of T3 and T4. If our results are shown to be pertinent in humans, the current replacement therapy of hypothyroidism should no longer be considered adequate, and might possibly lead to the development of new strategies of therapy combining administration of both $\mathrm{T} 4$ and $\mathrm{T} 3$, albeit at a much higher T4 to T3 molar ratio (possibly 14:1) than previously used clinically $(4: 1)(60)$.

\section{Appendix}

Table AI. Results of the Curve Fitting between Tissue T4 and Plasma T4 of Thyroidectomized Rats Infused with T4 Alone*

\begin{tabular}{|c|c|c|c|c|c|}
\hline Tissue & $\mathrm{Fit}^{\ddagger}$ & Formula & $\mathbf{R}^{2}$ & d.f. & $F$ \\
\hline Cortex & Power & {$[\mathrm{Cx}-\mathrm{T} 4]=0.59 \cdot[\mathrm{Pl}-\mathrm{T} 4]^{(1.12)}$} & 0.82 & 50 & 224 \\
\hline Cerebellum & Sigmoidal & {$[\mathrm{Cb}-\mathrm{T} 4]=\mathrm{e}^{(5.38-51.12 /[\mathrm{PI}-\mathrm{T} 4])}$} & 0.88 & 50 & 354 \\
\hline BAT & Sigmoidal & {$[\mathrm{BAT}-\mathrm{T} 4]=\mathrm{e}^{(5.13-27.09 /[\mathrm{PI}-\mathrm{T} 4])}$} & 0.59 & 50 & 71 \\
\hline Liver & Power & {$[\mathrm{L}-\mathrm{T} 4]=0.038 \cdot[\mathrm{Pl}-\mathrm{T} 4]^{(1.66)}$} & 0.79 & 49 & 181 \\
\hline Kidney & Linear & {$[\mathrm{K}-\mathrm{T} 4]=-6.62+0.86 \cdot[\mathrm{Pl}-\mathrm{T} 4]$} & 0.84 & 51 & 268 \\
\hline Lung & Sigmoidal & {$[\mathrm{Lu}-\mathrm{T} 4]=\mathrm{e}^{(5.26-50.96 /[\mathrm{PI}-\mathrm{T} 4])}$} & 0.86 & 48 & 302 \\
\hline Heart & Power & {$[\mathrm{H}-\mathrm{T} 4]=0.58 \cdot[\mathrm{Pl}-\mathrm{T} 4]^{(1.06)}$} & 0.91 & 49 & 472 \\
\hline Muscle & Power & {$[\mathrm{Mu}-\mathrm{T} 4]=1.61 \cdot[\mathrm{Pl}-\mathrm{T} 4]^{(0.97)}$} & 0.87 & 51 & 346 \\
\hline Spleen & Power & {$[S-T 4]=1.02 \cdot[\mathrm{Pl}-\mathrm{T} 4]^{(1.03)}$} & 0.90 & 50 & 426 \\
\hline
\end{tabular}

* Before curve fitting, and to combine the results of experiments A and B, raw data were transformed in percent of the mean value of the control group. The 95\% confidence interval for the normal plasma $\mathrm{T} 3$ and $\mathrm{T} 4$ concentrations was $87-113 \%$ of mean control values (T4: $36 \mathrm{ng} / \mathrm{ml}, \mathrm{T} 3: 0.84 \mathrm{ng} / \mathrm{ml}$ ). ${ }^{\ddagger}$ The curve with the best fitting (defined by the highest $\mathrm{R}^{2}$ and $F$ values) was selected. All fittings were significant with $P<0.001$.

Table AII. Results of the Curve Fitting between Tissue T3 and Plasma T4 of Thyroidectomized Rats Infused with T4 Alone*

\begin{tabular}{|c|c|c|c|c|c|}
\hline Tissue & Fit & Formula & $\mathbf{R}^{2}$ & d.f. & $F$ \\
\hline Cortex & Inverse & {$[\mathrm{Cx}-\mathrm{T} 3]=117-(1300 /[\mathrm{F}$} & 0.79 & 47 & 173 \\
\hline Cerebellum & Sigmoidal & {$[\mathrm{Cb}-\mathrm{T} 3]=\mathrm{e}^{(4.93-34.69 /[\mathrm{PI}-\mathrm{T} 4])}$} & 0.84 & 47 & 251 \\
\hline BAT & Sigmoidal & {$\left[\right.$ BAT-T3] $=\mathrm{e}^{(4.56-27.54 /[\mathrm{PI}-\mathrm{T} 4])}$} & 0.60 & 47 & 69 \\
\hline Liver & Linear & {$[\mathrm{L}-\mathrm{T} 3]=-8.22+0.77 \cdot[\mathrm{Pl}-\mathrm{T} 4]$} & 0.74 & 47 & 132 \\
\hline Kidney & Linear & {$[\mathrm{K}-\mathrm{T} 3]=1.05+0.80 \cdot[\mathrm{Pl}-\mathrm{T} 4]$} & 0.73 & 47 & 125 \\
\hline Lung & Power & {$[\mathrm{Lu}-\mathrm{T} 3]=0.47 \cdot[\mathrm{Pl}-\mathrm{T} 4]^{(1.03)}$} & 0.83 & 45 & 221 \\
\hline Heart & Power & {$[\mathrm{H}-\mathrm{T} 3]=0.53 \cdot[\mathrm{PI}-\mathrm{T} 4]^{(1.02)}$} & 0.82 & 48 & 224 \\
\hline Muscle & Power & {$[\mathrm{Mu}-\mathrm{T} 3]=1.39 \cdot[\mathrm{Pl}-\mathrm{T} 4]^{(0.89)}$} & 0.85 & 48 & 275 \\
\hline Spleen & Power & {$[\mathrm{S}-\mathrm{T} 3]=3.82 \cdot[\mathrm{Pl}-\mathrm{T} 4]^{(0.68)}$} & 0.89 & 49 & 385 \\
\hline
\end{tabular}

* See legend to Table AI.
Table AIII. Results of the Curve Fitting between Tissue T3 and Plasma T3 of Thyroidectomized Rats Infused with T4 Alone*

\begin{tabular}{lllllr}
\hline \multicolumn{1}{c}{ Tissue } & \multicolumn{1}{c}{ Fit } & \multicolumn{1}{c}{ Formula } & $\mathbf{R}^{2}$ & \multicolumn{1}{c}{ d.f. } & \multicolumn{1}{c}{$\boldsymbol{F}$} \\
\hline Cortex & Inverse & {$[\mathrm{CX}-\mathrm{T} 3]=128-(1923 /[\mathrm{Pl}-\mathrm{T} 3])$} & 0.88 & 45 & 334 \\
Cerebellum & Sigmoidal & {$[\mathrm{Cb}-\mathrm{T} 3]=\mathrm{e}^{(5.18-49.72 / \mathrm{PI}-\mathrm{T} 3])}$} & 0.86 & 43 & 265 \\
BAT & Sigmoidal & {$[\mathrm{BAT}-\mathrm{T} 3]=\mathrm{e}^{(4.75-39.94 /[\mathrm{PI}-\mathrm{T} 3])}$} & 0.53 & 47 & 53 \\
Liver & Linear & {$[\mathrm{L}-\mathrm{T} 3]=-19.94+1.18 \cdot[\mathrm{Pl}-\mathrm{T} 3]$} & 0.91 & 50 & 521 \\
Kidney & Linear & {$[\mathrm{K}-\mathrm{T} 3]=-11.60+1.22 \cdot[\mathrm{Pl}-\mathrm{T} 3]$} & 0.88 & 49 & 361 \\
Lung & Power & {$[\mathrm{Lu}-\mathrm{T} 3]=0.15 \cdot[\mathrm{Pl}-\mathrm{T} 3]^{(1.34)}$} & 0.91 & 47 & 469 \\
Heart & Sigmoidal & {$[\mathrm{H}-\mathrm{T} 3]=\mathrm{e}^{(5.15-60.51 / \mathrm{PI}-\mathrm{T} 3])}$} & 0.88 & 45 & 337 \\
Muscle & Power & {$[\mathrm{Mu}-\mathrm{T} 3]=0.53 \cdot[\mathrm{Pl}-\mathrm{T} 3]^{(1.15)}$} & 0.87 & 51 & 346 \\
Spleen & Power & {$[\mathrm{S}-\mathrm{T} 3]=1.73 \cdot[\mathrm{Pl}-\mathrm{T} 3]^{(0.89)}$} & 0.95 & 48 & 963
\end{tabular}

* See legend to Table AI.

\section{Acknowledgments}

The authors would like to thank Mrs. Socorro Durán, Mrs. M. Jesús Presas, and Mr. Arturo Hernández for their technical assistance, and to Prof. Rafael Herruzo, M.D., Ph. D., for his help in statistical analysis. We thank Drs. R. Thoma and H. Rökos from Henning-Berlin Gmbh for the gift of 3,5-[ $\left.{ }^{125} \mathrm{I}\right] \mathrm{T} 3$.

This work was supported by the Fondo de Investigaciones de la Seguridad Social (B.A.E. 93/5168 and 94/5082, Proyecto 92/0888) and by Henning Berlin Gmbh, Germany.

\section{References}

1. Pilo, A., G. Iervasi, F. Vitek, M. Ferdeghini, F. Cazzuola, and R. Bianchi. 1990. Thyroidal and peripheral production of 3,5,3'-triiodothyronine in humans by multicompartmental analysis. Am. J. Physiol. 258:E715-E726.

2. Schroeder van der Elst, J. P., and D. van der Heide. 1990. Thyroxine, 3,5,3'triiodothyronine, and 3,3',5'-triiodothyronine concentrations in several tissues of the rat: effects of amiodarone and desethylamiodarone on thyroid hormone metabolism. Endocrinology. 127:1656-1664.

3. Schroeder van der Elst, J. P., and D. van der Heide. 1990. Effects of 5,5' Diphenylhydantoin on thyroxine and 3,5,3'-triiodothyronine concentrations in several tissues of the rat. Endocrinology. 126:186-191.

4. Schroeder van der Elst, J. P., and D. van der Heide. 1991. In vivo effects of flavonoid EMD 21388 on thyroid hormone secretion and metabolism. Am. J. Physiol. 261:E227-E232.

5. Schroeder van der Elst, J. P., and D. van der Heide. 1992. Effects of streptozotocin-induced diabetes and food restriction on the quantities and source of thyroxine and 3,5,3' triiodothyronine in rat tissues. Diabetes. 41:147-152.

6. Obregón, M. J., F. Roelfsema, F. Escobar del Rey, G. Morreale de Escobar, and A. Querido. 1976. Are there hidden pools of tri-iodothyrone? Acta Endocrinol. Suppl. 204:30A. (Abstr.)

7. Obregón, M. J., F. Roelfsema, G. Morreale de Escobar, F. Escobar del Rey, and A. Querido. 1979. Exchange of triiodothyronine derived from thyroxine with circulating triiodothyronine as studied in the rat. Clin. Endocrinol. 10:305-315.

8. Silva, J. E., and P. R. Larsen. 1977. Pituitary nuclear 3,5,3' triiodothyronine and thyrotropin secretion: an explanation for the effect of thyroxine. Science (Wash. DC). 198:617-620.

9. Larsen, P. R., J. E. Silva, and M. M. Kaplan. 1981. Relationships between circulating and intracellular thyroid hormones. Endocrinol. Rev. 2:87-102.

10. Leonard, J. L., and T. Visser. 1986. Biochemistry of deiodination. In Thyroid Hormone Metabolism. G. Henneman, editor. Marcel Dekker, New York. 189-230.

11. Kaplan, M. M. 1986. Regulatory influences on iodothyronine deiodination in animal Tissues. In Thyroid Hormone Metabolism. G. Henneman, editor. Marcel Dekker, New York. 231-254.

12. Silva, J. E., and P. R. Larsen. 1978. Contribution of plasma triiodothyronine and local thyroxine monodeiodination to triiodothyronine receptor saturation in pituitary, liver and kidney of hypothyroid rats. J. Clin. Invest. 61:1247-1259.

13. Silva, J. E., T. E. Dick, and P. R. Larsen. 1978. The contribution of local tissue thyroxine monodeiodination to the nuclear 3,5,3'-triiodothyronine in pituitary, liver and kidney of euthyroid rats. Endocrinology. 103:1196-1207.

14. Silva, J. E., J. L. Leonard, F. R. Crantz, and P. R. Larsen. 1982. Evidence of two tissue-specific pathways for in vivo thyroxine 5 '-deiodination in the rat. J. Clin. Invest. 69:1176-1184.

15. Crantz, F. R., J. E. Silva, and P. R. Larsen. 1982. An analysis of the sources and quantity of 3,5,3'-triiodothyronine specifically bound to nuclear receptors in rat cerebral cortex and cerebellum. Endocrinology. 110:367-375. 
16. van Doorn, J., D. van der Heide, and F. Roelfsema. 1982. Sources and quantity of 3,5,3'-triiodothyronine in several tissues of the rat. J. Clin. Invest. 72:1778-1792.

17. van Doorn, J., F. Roelfsema, and D. van der Heide. 1982. Contribution from local conversion of thyroxine to $3,5,3^{\prime}$-triiodothyronine to intracellular 3,5,3'-triiodothyronine in several organs in hypothyroid rats at isotopic equilibrium. Acta Endocrinol. 1001:386-396.

18. van Doorn, J., D. van der Heide, and F. Roelfsema. 1984. The contribution of local thyroxine monodeiodination to intracellular 3,5,3'-triiodothyronine in several tissues of hyperthyroid rats at isotopic equilibrium. Endocrinology. 115:174-182.

19. van Doorn, J., F. Roelfsema, and D. van der Heide. 1984. The influence of partial food deprivation on the quantity and source of triiodothyronine in several tissues of athyreotic thyroxine-maintained animals. Endocrinology 115:705-711.

20. Silva, J. E., and P. S. Matthews. 1984. Production rates and turnover of triiodothyronine in rat-developing cerebral cortex and cerebellum. Responses to hypothyroidism. J. Clin. Invest. 74:1035-1049.

21. Ruiz de Oña, C., M. J. Obregón, F. Escobar del Rey, and G. Morreale de Escobar. 1988. Development changes in rat brain 5'-deiodinase and thyroid hormones during the fetal period: the effects of fetal hypothyroidism and maternal thyroid hormones. Pediatr. Res. 24:588-594.

22. Calvo, R. M., M. J. Obregón, C. Ruiz de Oña, F. Escobar del Rey, and G. Morreale de Escobar. 1990. Hypothyroidism, as studied in rats: crucial role of maternal thyroxine but not of 3,5,3'-triiodothyronine in the protection of the fetal brain. J. Clin. Invest. 86:889-899.

23. Silva, J. E., and P. R. Larsen. 1985. Potential of brown adipose tissue type II thyroxine 5 -deiodinase as a local and systemic source of triiodothyronine in rats. J. Clin. Invest. 76:2296-2305.

24. Fernández, J. A., T. Mampel, F. Villarroya, and R. Iglesias. 1987. Direct assessment of brown adipose tissue as a site of systemic tri-iodothyronine production in the rat. Biochem. J. 243:281-284.

25. Burger, A. 1986. Nondeiodinative pathways of thyroid hormone metabolism. In Thyroid Hormone Metabolism. G. Henneman, editor. Marcel Dekker, New York. 255-276.

26. Krenning, E. P., and R. Docter. 1986. Plasma membrane transport of thyroid hormone. In Thyroid Hormone Metabolism. G. Henneman, editor. Marcel Dekker, New York. 107-132.

27. Larsen, P. R., and S. H. Ingbar. 1992. The thyroid gland. In William's Textbook of Endocrinology, 8th Edition. J. D. Wilson and D. W. Foster, editors W. B. Saunders Co., Philadelphia. 357-488.

28. Utiger, R. D. 1989. Hypothyroidism. In Endocrinology, 2nd Edition. L. J. DeGroot, editor. W. B. Saunders Co., Philadelphia. 702-721.

29. Obregón, M. J., A. Pascual, G. Morreale de Escobar, and F. Escobar de Rey. 1979. Pituitary and plasma thyrotropin, thyroxine and triiodothyronine after hyperthyroidism. Endocrinology. 104:1467-1473.

30. Morreale de Escobar, G., R. M. Pastor, M. J. Obregón, and F. Escobar del Rey. 1985. Effects of maternal hypothyroidism on the weight and thyroid hormone content of rat embryonic tissues. Endocrinology. 117:1890-1901.

31. Morreale de Escobar, G., R. Calvo, F. Escobar, and M. J. Obregón. 1994 Thyroid hormones in tissues from fetal and adult rats. Endocrinology. 134:2410 2415.

32. Santisteban, P., M. J. Obregón, A. Rodríguez-Peña, L. Lamas, F. Escoba del Rey, and G. Morreale de Escobar. 1982. Are Iodine-deficient rats euthyroid? Endocrinology. 110:1780-1789.

33. Ruiz de Oña, C., G. Morreale de Escobar, R. M. Calvo, F. Escobar del Rey, and M. J. Obregón. 1991. Thyroid hormone and 5'-deiodinase in the rat fetus late in gestation. Effects of maternal hypothyroidism. Endocrinology. 128:422-432.

34. Obregón M. J., C. Ruiz de Oña, A. Hernández, R. Calvo, F. Escobar del Rey, and G. Morreale de Escobar. 1989. Thyroid hormones and 5'-dediodinase in rat brown adipose tissue during fetal life. Am. J. Physiol. 257:E625-E631.

35. Lowry, O. H., N. J. Rosebrough, A. L. Farr, and R. J. Randall. 1951. Protein measurement with the Folin phenol reagent. J. Biol Chem 193:265-275. 36. Campos-Barros, A., R. Kohler, F. Muller, M. Eravci, H. Meinhold, W. Wesemann, and A. Baugmartner. 1993. The influence of sleep deprivation on thyroid hormone metabolism in rat frontal cortex. Neurosci. Lett. 162:145-148.

37. Snedecor, G. W., and W. G. Cochran. 1980. Statistical Methods, 7th Ed. Iowa State University Press, Ames, IA. 507 pp.

38. DiStefano, J. J. 1985. Modeling approaches and models of the distribution and disposal of thyroid hormones. In Thyroid Hormone Metabolism. G. Henneman, editor. Marcel Dekker, New York. 39-76.

39. Ruiz-Marcos, A., P. Cartagena-Abella, J. R. Martínez-Galán, R. Calvo, G. Morreale de Escobar, and F. Escobar del Rey. 1994. Thyroxine treatment and the recovery of pyramidal cell of the cerebral cortex from changes induced by adult-onset hypothyroidism. J. Neurobiol. 25:808-818.

40. García, M. D., F. Escobar del Rey, and G. Morreale de Escobar. 1976. Thyrotropin-releasing hormone and thyroid hormone interactions on thyrotropin secretion in the rat. Lack of inhibiting effects of small doses of triiodo-L-thyronine in the hypothyroid rat. Endocrinology. 98:203-213.

41. Weeke, J., and H. J. G. Gundersen. 1978. Circadian and 30 minutes variation in serum TSH and thyroid hormones in normal subjects. Acta Endocrinol. 89:659-672.

42. Baumgarter, A., A. Campos-Barros, and H. Meinhold. 1992. Thyroid hormones and depressive illness: implications for clinical and basic research. Acta Med. Austriaca. 19:98-102.

43. Rubio, A., C. Osuna, and J. M. Guerrero. 1991. Beta and alfa-adrenergic mechanisms are involved in regulation of rat pineal type II thyroxine 5 '-deiodinase activity during development. Endocrinology. 128:1661-1667.

44. Siegrist-Kaiser, C. A., C. Juge-Aubry, M. P. Tranter, D. M. Ekenbarger, and J. L. Leonard. 1990. Thyroxine-dependent modulation of actin polymerization in cultured astrocytes: a novel, extra-nuclear action of thyroid hormone. J. Biol. Chem. 265:5286-5302.

45. Surks, M. I., and J. H. Oppenheimer. 1977. Concentration of 1-thyroxine and 1-triiodothyronine specifically bound to nuclear receptors in rat liver and kidney. Quantitative evidence favoring a major role of $\mathrm{T} 3$ in thyroid hormone action. J. Clin. Invest. 60:555-562.

46. Pascual, A., F. Montiel, and A. Aranda. 1987. Effects of iopanoic acid on thyroid hormone receptor, growth hormone production, and triiodothyronine generation from thyroxine in pituitary GH1 cells. Endocrinology. 120:1089-1096.

47. Shapiro, L. E., and M. I. Surks. 1990. Hypothyroidism. In Principles and Practice of Endocrinology and Metabolism. K. L. Becker, editor. J. B. Lippincott Co. Philadelphia. 363-370

48. Morreale de Escobar, G., R. Calvo, M. J. Obregón, and F. Escobar del Rey. 1992. Homeostasis of brain T3 in rat fetuses and their mothers: effects of thyroid status and iodine deficiency. Acta Med. Austriaca. 19:110-116.

49. Leonard, J. L., M. M. Kaplan, T. J. Visser, J. E. Silva, and P. R. Larsen. 1981. Cerebral cortex responds rapidly to thyroid hormones. Science (Wash. DC). 214:571-573.

50. Obregón, M. J., P. R. Larsen, and J. E. Silva. 1986. The role of 5,3',5'triiodothyronine in the regulation of type II iodothyronine 5'-deiodinase in the rat cerebral cortex. Endocrinology. 119:2186-2192.

1. Balsam, A., and S. H. Ingbar. 1979. Observations on the factors that control the generation of triiodothyronine from thyroxine in rat liver and the nature of the defect induced by fasting. J. Clin. Invest. 63:1145-1156.

52. Otten, M. H., J. A. Mol, and T. J. Visser. 1983. Sulfation preceding deiodination of iodothyronines in rat hepatocytes. Science (Wash. DC). 211:8183.

53. Moreno, M., M. J. Berry, C. Horst, R. Thoma, F. Goglia, J. W. Harney, P. R. Larsen, and T. J. Visser. 1994. Activation and inactivation of thyroid hormone by type I iodothyronine deiodinase. FEBS Lett. 344:143-146.

54. Hurd, R. E., F. Santini, B. Lee, P. Naim, and I. J. Chopra. 1993. A study of the 3,5, 3'-triiodothyronine sulfation activity in the adult and fetal rat. Endocrinology. 133:1951-1955.

55. Santini, F. I. J. Chopra, S. Y Wu, D. H Salomon, and G. N. Chua-Teco. 1992. Metabolism of 3,5, 3'-triiodothyronine sulfate by tissues of the fetal rat: a consideration of the role of desulfation of 3,5, 3'-triiodothyronine sulfate as a source of T3. Pediatr. Res. 31:541-544.

56. Esfandiari, A., J. M. Gavaret, A. M. Lennon, M. Pierre, and F. Courtin. 1994. Sulfation after deiodination of 3,5, 3'-triiodothyronine in rat cultured astrocytes. Endocrinology. 135:2086-2092.

57. Escobar-Morreale, H., M. J. Obregón, R. Calvo, F. Escobar del Rey, G. and Morreale de Escobar. 1993. Continuous infusion of different doses of thyroxine (T4) or triiodothyronine (T3) in thyroidectomized rats: circulating and tissue levels of T4 and T3. 67th Meeting of the American Thyroid Association, Tampa, FL. T-49. (Abstr.)

58. Escobar-Morreale, H., M. J. Obregón, F. Escobar del Rey, and G. Morreale de Escobar. 1994. Circulating and tissue levels of T4 and T3, and 5'-iodothyronine deiodinase activities, in thyroidectomized rats infused with different doses of T4, T3, or T4 plus T3. 76th Meeting of the Endocrine Society, Anaheim, CA. (Abstr.)

59. Fish, L. H., H. L. Schwartz, J. Cavanaugh, M. W. Steffes, J. P. Bantle, and J. H. Oppenheimer. 1987. Replacement dose, metabolism and bioavailability of levothyroxine in the treatment of hypothyroidism: role of triiodothyronine in pituitary feedback in humans. N. Engl. J. Med. 316:764-770.

60. Hershman, J. M. 1986. Hypothyroidism and hyperthyroidism. In N. Lavin, editor. Manual of Endocrinology and Metabolism. Little, Brown and Co., Boston. $365-378$ 